Prepared in cooperation with the Arkansas Natural Resources Commission

\title{
Estimated Water Use in Arkansas, 2010
}

Scientific Investigations Report 2015-5062 
Cover, Irrigation well in northeastern Arkansas (U.S. Geological Survey photograph by Terrance W. Holland, 2009). 


\section{Estimated Water Use in Arkansas, 2010}

By Aaron L. Pugh and Terrance W. Holland

Prepared in cooperation with the Arkansas Natural Resources Commission

Scientific Investigations Report 2015-5062 


\title{
U.S. Department of the Interior SALLY JEWELL, Secretary
}

\section{U.S. Geological Survey \\ Suzette M. Kimball, Acting Director}

\author{
U.S. Geological Survey, Reston, Virginia: 2015
}

For more information on the USGS - the Federal source for science about the Earth, its natural and living resources, natural hazards, and the environment—visit http://www.usgs.gov or call 1-888-ASK-USGS.

For an overview of USGS information products, including maps, imagery, and publications, visit http://www.usgs.gov/pubprod/.

Any use of trade, firm, or product names is for descriptive purposes only and does not imply endorsement by the U.S. Government.

Although this information product, for the most part, is in the public domain, it also may contain copyrighted materials as noted in the text. Permission to reproduce copyrighted items must be secured from the copyright owner.

Suggested citation:

Pugh, A.L., and Holland, T.W., 2015, Estimated water use in Arkansas, 2010: U.S. Geological Survey Scientific Investigations Report 2015-5062, 33 p., http://dx.doi.org/10.3133/sir20155062.

ISSN 2328-0328 (online) 


\section{Contents}

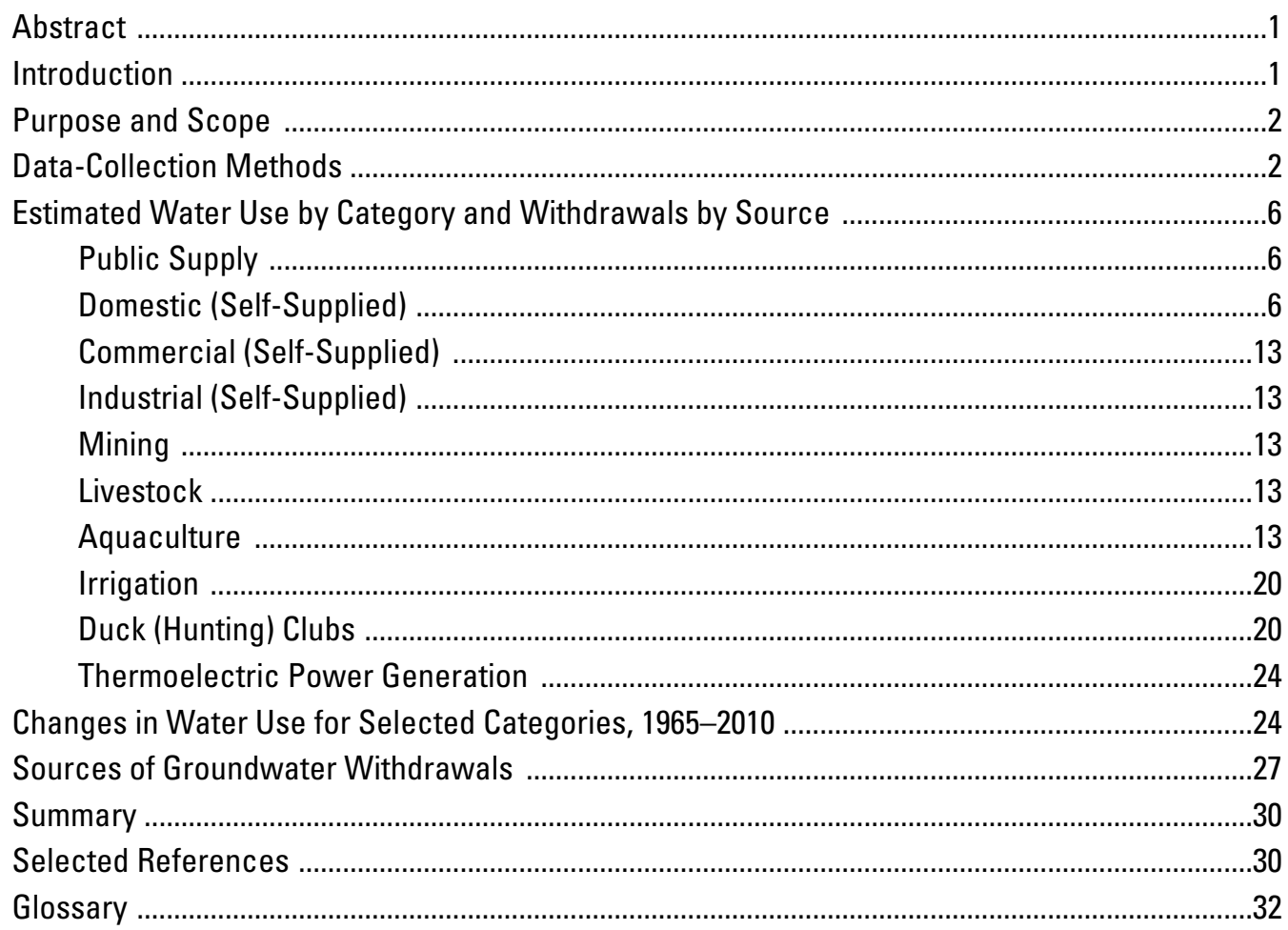

\section{Figures}

1. Maps showing well locations within major hydrogeologic units and

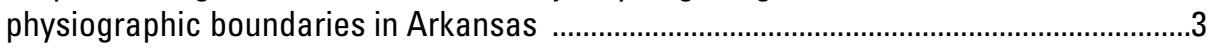

2. Map showing major surface-water sources ..............................................................4

3. Map showing counties where selected water-use data are reported at Conservation District offices ..........................................................................................5

4. Maps showing total water, groundwater, and surface-water use by county for Arkansas, 2010

5. Graph showing total water, groundwater, and surface-water use in Arkansas by category, 2010

6. Graph showing total water, groundwater, and surface-water use in Arkansas, 1965-2010

7. Graph showing total water and irrigation water use for groundwater and surface water in Arkansas, 1965-2010

8. Graph showing groundwater and surface-water use and population served for public-supply systems in Arkansas, 1965-2010 


\section{Tables}

1. Groundwater, surface-water, and total water withdrawals by county for Arkansas, 2010 .7

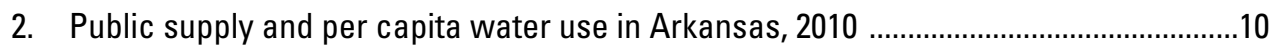

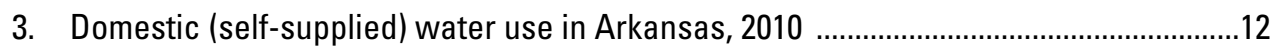

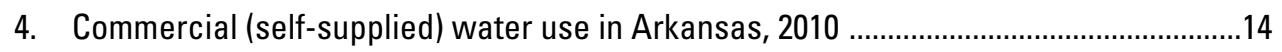

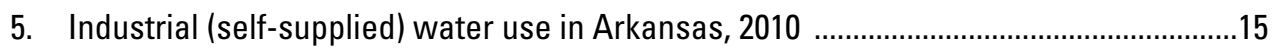

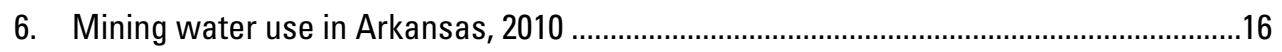

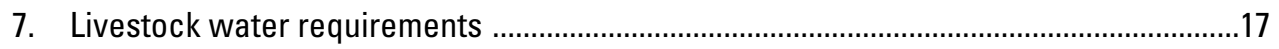

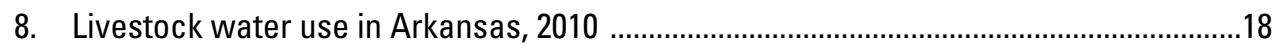

9. Aquaculture water use in Arkansas, 2010 ...........................................................19

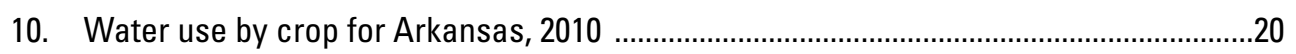

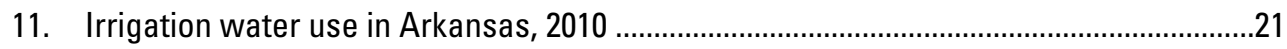

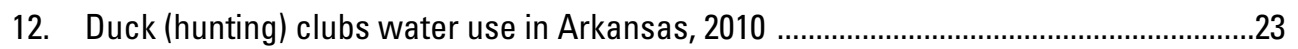

13. Thermoelectric power water use in Arkansas, 2010 .....................................................25

14. Changes in water use for selected categories in Arkansas, 1965-2010 ........................26

15. Groundwater use by major aquifer in Arkansas, 2010 .................................................28 


\section{Conversion Factors}

Inch/Pound to SI

\begin{tabular}{|c|c|c|}
\hline Multiply & By & To obtain \\
\hline \multicolumn{3}{|c|}{ Length } \\
\hline inch (in.) & 2.54 & centimeter (cm) \\
\hline foot $(\mathrm{ft})$ & 0.3048 & meter (m) \\
\hline mile (mi) & 1.609 & kilometer (km) \\
\hline \multicolumn{3}{|c|}{ Area } \\
\hline acre & 4,047 & square meter $\left(\mathrm{m}^{2}\right)$ \\
\hline acre & 0.4047 & hectare (ha) \\
\hline acre & 0.4047 & square hectometer $\left(\mathrm{hm}^{2}\right)$ \\
\hline acre & 0.004047 & square kilometer $\left(\mathrm{km}^{2}\right)$ \\
\hline square foot $\left(\mathrm{ft}^{2}\right)$ & 0.09290 & square meter $\left(\mathrm{m}^{2}\right)$ \\
\hline square mile $\left(\mathrm{mi}^{2}\right)$ & 259.0 & hectare (ha) \\
\hline square mile $\left(\mathrm{mi}^{2}\right)$ & 2.590 & square kilometer $\left(\mathrm{km}^{2}\right)$ \\
\hline \multicolumn{3}{|c|}{ Volume } \\
\hline gallon (gal) & 3.785 & liter (L) \\
\hline gallon (gal) & 0.003785 & cubic meter $\left(\mathrm{m}^{3}\right)$ \\
\hline gallon (gal) & 3.785 & cubic decimeter $\left(\mathrm{dm}^{3}\right)$ \\
\hline million gallons (Mgal) & 3,785 & cubic meter $\left(\mathrm{m}^{3}\right)$ \\
\hline cubic foot $\left(\mathrm{ft}^{3}\right)$ & 0.02832 & cubic meter $\left(\mathrm{m}^{3}\right)$ \\
\hline acre-foot (acre-ft) & 1,233 & cubic meter $\left(\mathrm{m}^{3}\right)$ \\
\hline acre-foot (acre-ft) & 0.001233 & cubic hectometer $\left(\mathrm{hm}^{3}\right)$ \\
\hline \multicolumn{3}{|c|}{ Flow rate } \\
\hline cubic foot per second $\left(\mathrm{ft}^{3} / \mathrm{s}\right)$ & 0.02832 & cubic meter per second $\left(\mathrm{m}^{3} / \mathrm{s}\right)$ \\
\hline gallon per day (gal/d) & 0.003785 & cubic meter per day $\left(\mathrm{m}^{3} / \mathrm{d}\right)$ \\
\hline million gallons per day (Mgal/d & 0.04381 & cubic meter per second $\left(\mathrm{m}^{3} / \mathrm{s}\right)$ \\
\hline
\end{tabular}

\section{Datum}

Horizontal coordinate information is referenced to the North American Datum of 1983 (NAD 83). Altitude, as used in this report, refers to distance above the North American Vertical Datum of 1988 (NAVD 88).

\section{Supplemental Information}

Volume in acre-foot (acre-ft) may be converted to gallons (gal) as follows:

gal $=$ acre $-f t \times 325,851.429$ 



\title{
Estimated Water Use in Arkansas, 2010
}

\author{
By Aaron L. Pugh and Terrance W. Holland
}

\section{Abstract}

The Arkansas Natural Resources Commission (ANRC) conducts an annual inventory of reported groundwater and surface-water withdrawals in Arkansas in cooperation with the U.S. Geological Survey (USGS). This report describes withdrawals from groundwater and surface-water resources in Arkansas for 2010. The report compiles withdrawals by county for 10 categories of water use-public supply, domestic (self-supplied), commercial (self-supplied), industrial (self-supplied), mining, livestock, aquaculture, irrigation, duck (hunting) clubs, and thermoelectric power generation. Water-use trends in Arkansas from 1965 to 2010 and sources of groundwater withdrawals also are described.

During 2010, total withdrawals from groundwater and surface-water sources in Arkansas were 11,300 million gallons per day (Mgal/d). Of the total withdrawn, about 69 percent (7,790 Mgal/d) was from groundwater. Public-supply systems served about 94 percent of Arkansas' population. Public-supply total withdrawals were $429 \mathrm{Mgal} / \mathrm{d}$, with about 69 percent from surface-water sources. The statewide average of per capita residential use from public-supply systems was about 155 gallons per day (gal/d). The domestic (selfsupplied) water use was $12.8 \mathrm{Mgal} / \mathrm{d}$. Total commercial (selfsupplied) water use was $11.7 \mathrm{Mgal} / \mathrm{d}$. Total industrial (selfsupplied) water use was $276 \mathrm{Mgal} / \mathrm{d}$. Total mining water use was $44.3 \mathrm{Mgal} / \mathrm{d}$. Total livestock water use was $39.0 \mathrm{Mgal} / \mathrm{d}$. Total aquaculture water use was $268 \mathrm{Mgal} / \mathrm{d}$. Irrigation water use totaled $8,720 \mathrm{Mgal} / \mathrm{d}$. Total duck (hunting) club water use was $216 \mathrm{Mgal} / \mathrm{d}$. Total thermoelectric power water use was $1,540 \mathrm{Mgal} / \mathrm{d}$.

The three water-use categories with the largest withdrawals and their effects on total water use were examined. Total water use in Arkansas has increased about 428 percent between 1965 and 2010. Total groundwater use increased about 533 percent and total surface-water use increased about 289 percent. Since about 2000, total water use in Arkansas has plateaued, peaking in 2005. The plateauing of total water use is the result of decreasing surface-water use in the irrigation, thermoelectric power, and public-supply categories offsetting the continuing increases in groundwater use in the irrigation category. An examination of total water use and irrigation water-use changes over time demonstrates the increasing dominance of groundwater withdrawals for irrigation on Arkansas' total water use. Total irrigation water use in Arkansas between 1965 and 2010 has increased about 652 percent. Withdrawals for thermoelectric power water use in Arkansas have continuously accounted for about half of the State's total surface-water use for the period 1965-2010. Thermoelectric power water use in Arkansas between 1965 and 2010 increased 264 percent. The percent of Arkansas' population served by public water suppliers has continued to increase while the percentage of the State's total water use withdrawn by public water suppliers has remained relatively constant. Public-supply water use in Arkansas between 1965 and 2010 increased about 238 percent. Regardless of continuing increases in population, since about 2000, total public-supply water use in Arkansas has plateaued at about $425 \mathrm{Mgal} / \mathrm{d}$.

Groundwater withdrawals comprised about 69 percent of the total amount of water used in Arkansas in 2010. Four aquifers in Arkansas account for more than 99 percent of the total groundwater withdrawals. The aquifers in deposits of Quaternary age supplied about 97 percent of all groundwater withdrawals. The Sparta-Memphis aquifer supplied about 2.5 percent of all groundwater withdrawals, the Wilcox aquifer supplied about 0.5 percent of all groundwater withdrawals, and the Paleozoic aquifer supplied about 0.3 percent of all groundwater withdrawals.

\section{Introduction}

Water is one of Arkansas' most valuable natural resources. Much of the State's agriculture and industry is dependent upon having an adequate supply of quality water. The Arkansas Natural Resources Commission (ANRC) conducts an annual inventory of reported groundwater and surface-water withdrawals in Arkansas in cooperation with the U.S. Geological Survey (USGS). Data collected during this inventory are shared by State and Federal agencies to document the State's total water use and to facilitate planning the most effective use of Arkansas' water resources for the economic, social, and environmental well-being for the people of Arkansas and the Nation. 
An inventory of water use in the United States has been conducted every 5 years since 1950 by the USGS (MacKichan, 1951, 1957; MacKichan and Kammerer, 1961; Murray, 1968; Murray and Reeves, 1972, 1977; Solley and others, 1983, 1988, 1993, 1998; Hutson and others, 2004; Kenny and others, 2009). In 1978, the National Water-Use Information Program was initiated by the USGS to establish a nationwide water-use database. In 1985, the ANRC and the USGS began a water-use program that provides for the collection, storage, and dissemination of accurate wateruse information for Arkansas within a consistent national framework. The 2010 water-use data for Arkansas have been aggregated with data for the rest of the United States that is included in a report on water use for the Nation (Maupin and others, 2014).

Groundwater and surface-water sources are abundant in many areas of Arkansas. Major groundwater sources (fig. 1) are located in deposits of Quaternary age, the Cockfield Formation, the Sparta and Memphis Sands, the Cane River Formation, the undifferentiated Wilcox Group, the Clayton Formation, the Nacatoch Sand, the Tokio Formation, the Trinity Group, and the undifferentiated rocks of Paleozoic age. Hereafter, these groundwater sources will be referred to as the alluvial, Cockfield, Sparta-Memphis, Cane River, Wilcox, Clayton, Nacatoch, Tokio, Trinity, and Paleozoic aquifers. Major surface-water sources include the Arkansas, White, Saline, and Ouachita Rivers and Beaver, Bull Shoals, Greers Ferry, Maumelle, and Winona Lakes (fig. 2).

\section{Purpose and Scope}

The purpose of this report is to describe withdrawals from groundwater and surface-water resources in Arkansas for 2010 . The report compiles withdrawals by county (fig. 3) for 10 categories of water use-public supply, domestic (self-supplied), commercial (self-supplied), industrial (selfsupplied), mining, livestock, aquaculture, irrigation, duck (hunting) clubs, and thermoelectric power generation. Wateruse trends in Arkansas from 1965 to 2010 and sources of groundwater withdrawals also are described.

\section{Data-Collection Methods}

Site-specific water-use data for several categories are collected and compiled annually by the ANRC in cooperation with the USGS. Water users that withdraw 1 acre-foot (acre-ft) or more of surface water per year or wells with the capability of pumping 50,000 gallons per day (gal/d) or more of groundwater report their withdrawals annually. Data for the irrigation, livestock, aquaculture, and duck (hunting) club categories are reported through the Conservation District offices in selected counties (fig. 3). Water-use data for each of the other categories are reported to the ANRC. Site-specific water-use data for irrigation, livestock, and duck (hunting) clubs, public supply, commercial (self-supplied), industrial (self-supplied), mining, and power generation are stored in the Arkansas Water-Use Data Base (WUDBS) maintained by the USGS. Information about amounts of water withdrawn, sources of water, how the water was used, and how much water was returned is available to water-resources managers and policy makers through the WUDBS by contacting ANRC or USGS.

Because of incomplete reporting, it is necessary in some cases to supplement these data with data from other sources. These sources include public agencies, industries, public utilities, other organizations, and individuals. Principal contributors include the Arkansas Agricultural Experiment Station, Arkansas Department of Environmental Quality, Arkansas Department of Health, Arkansas Department of Parks and Tourism, Arkansas Electric Cooperative, Arkansas Geological Survey, Arkansas Industrial Development Commission, Entergy Arkansas, Arkansas State Highway and Transportation Department, University of Arkansas Cooperative Extension Service, National Agricultural Statistics Service, Natural Resources Conservation Service, Southwest Power Administration, U.S. Army Corps of Engineers, U.S. Department of Energy, and U.S. Fish and Wildlife Service.

Some estimates are made by the USGS based on population (U.S. Department of Commerce, U.S. Census Bureau, 2010) and average consumptive-use rates for water-use categories for which data are not available or are incomplete. After sufficient data are collected from all available sources, these data are aggregated by county for each water-use category and by aquifer for each county. 

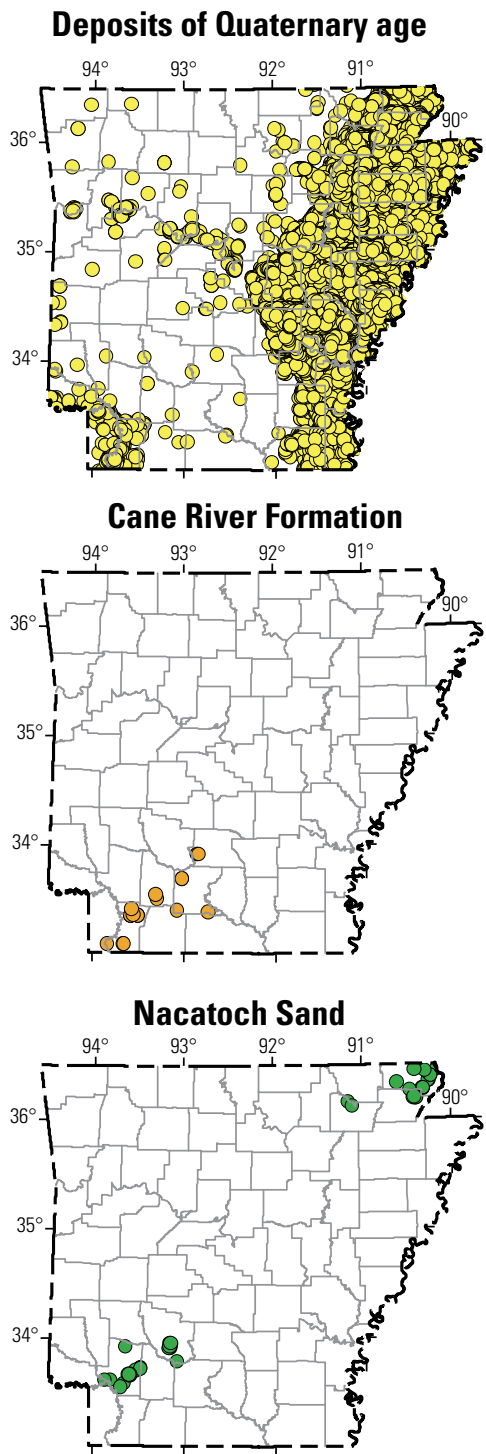

Rock of Paleozoic age, undifferentiated

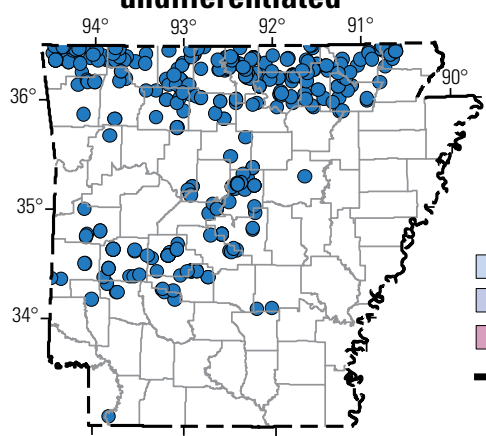

Base modified from U.S. Geological Survey 1:100,000-scale digital data
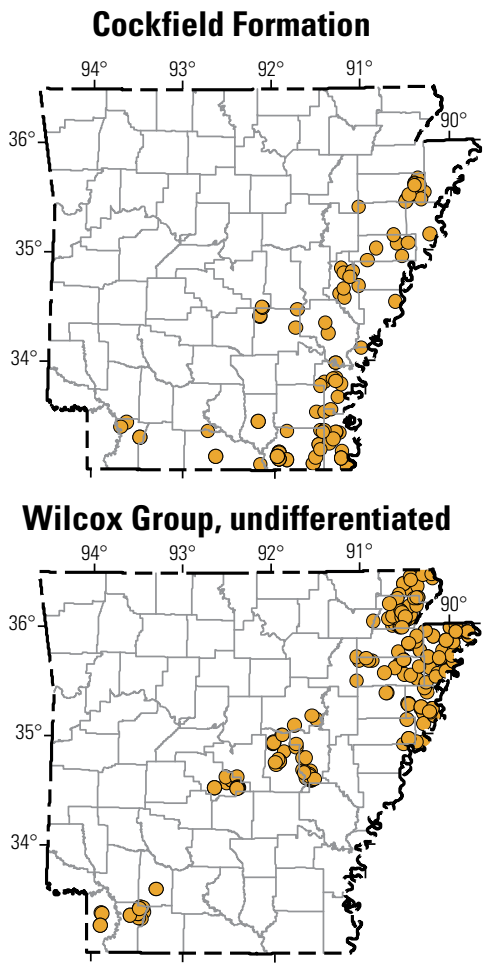

Tokio Formation
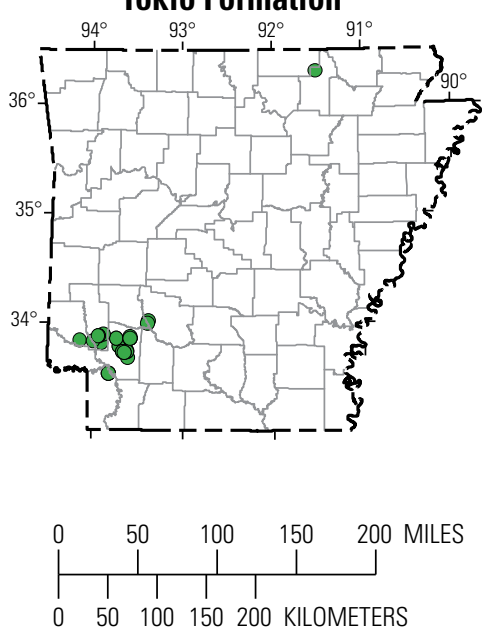

EXPLANATION

Physiographic sections

Springfield-Salem Plateau $\square$ Ouachita Mountains

Boston Mountains $\quad \square$ West Gulf Coastal Plain

Arkansas Valley $\quad \square$ Mississippi Alluvial Plain

Physiographic division Physiographic section boundary boundary

Well locations completed in stratigraphic unit age:
o Quaternary
- Cretaceous
- Tertiary
- Paleozoic
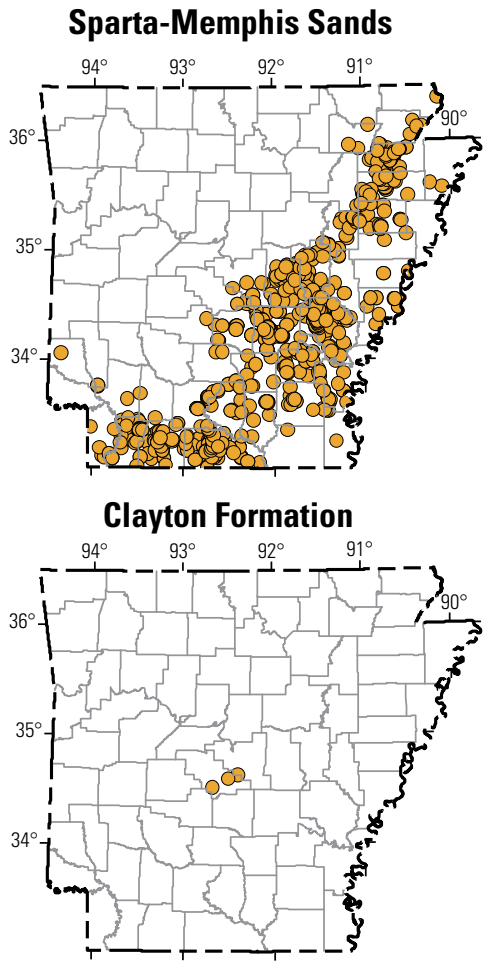

Trinity Group

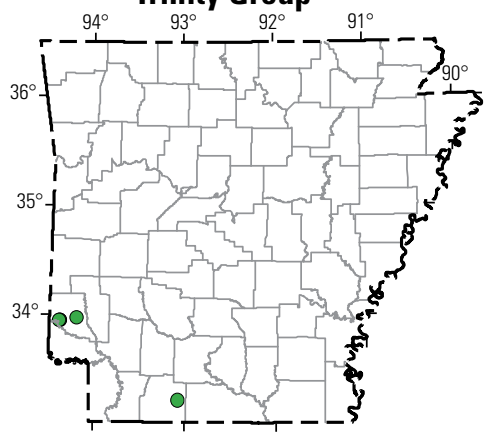

Physiographic boundaries

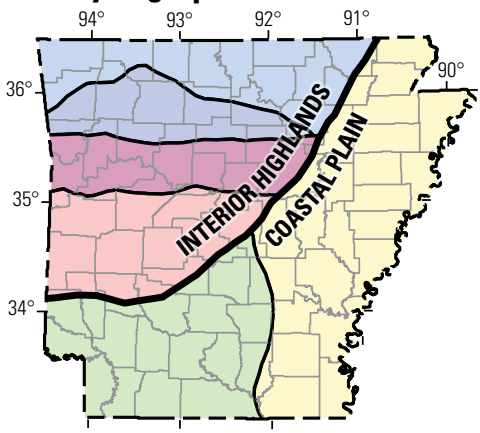

Physiographic division and section boundaries from Fenneman and Johnson (1946)

Figure 1. Well locations within major hydrogeologic units and physiographic boundaries in Arkansas. 


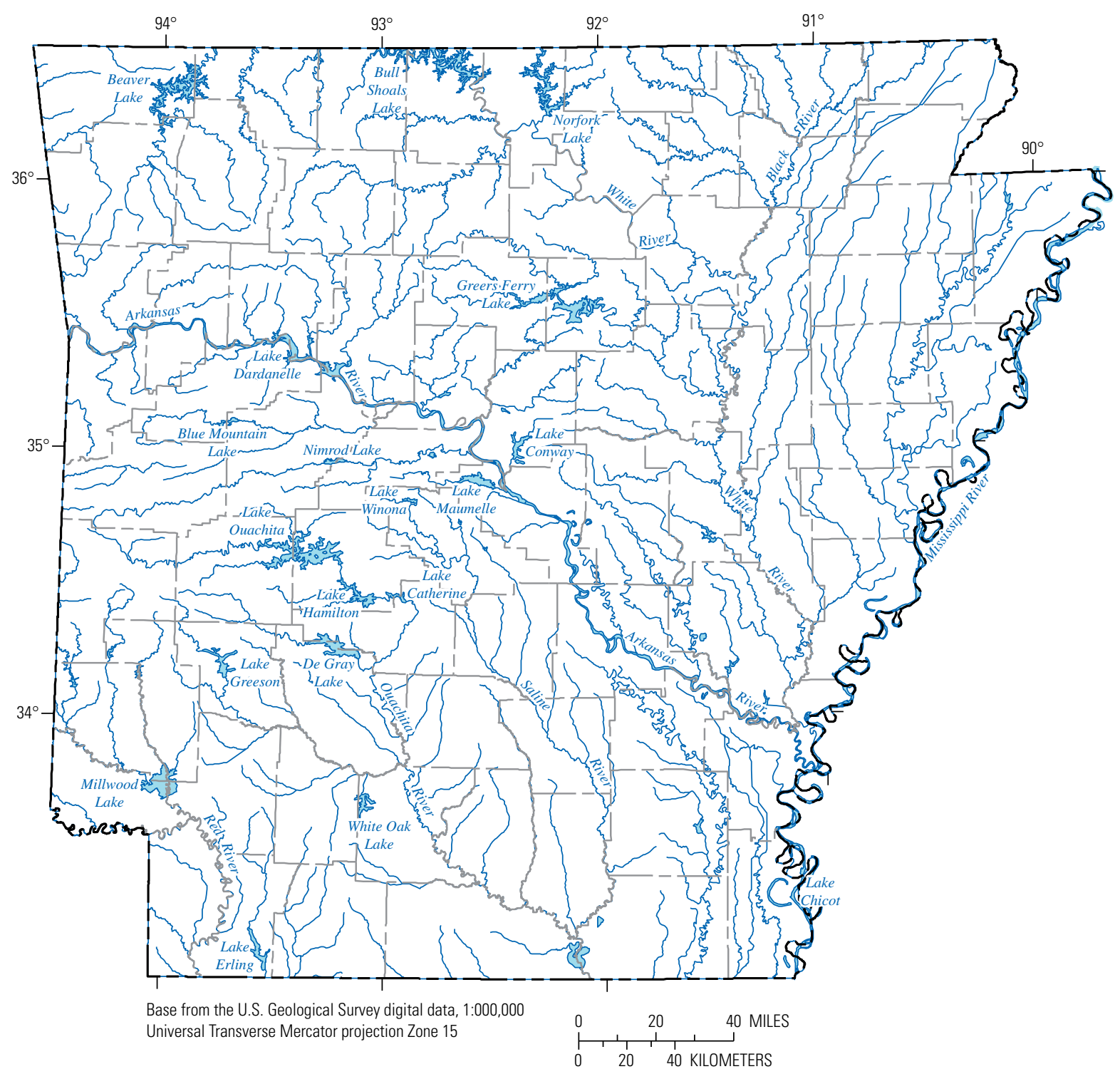

Figure 2. Major surface-water sources. 


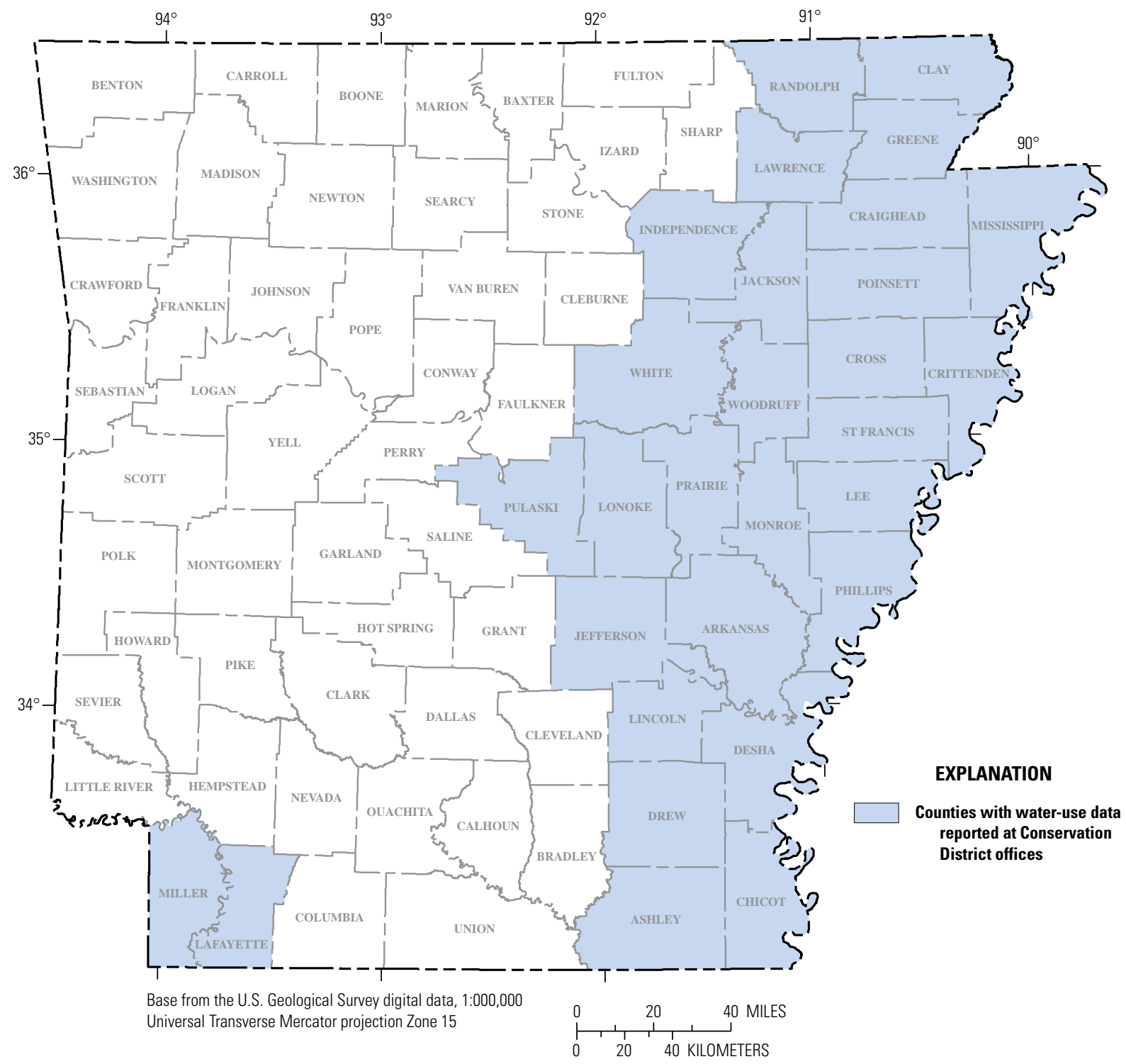

Figure 3. Counties where selected water-use data are reported at Conservation District offices. 


\section{Estimated Water Use by Category and Withdrawals by Source}

During 2010, total withdrawals from groundwater and surface-water sources in Arkansas were 11,300 million gallons per day (Mgal/d) (table 1). Of the total withdrawn, about 69 percent (7,790 Mgal/d) was from groundwater, and the remaining 31 percent $(3,540 \mathrm{Mgal} / \mathrm{d})$ was from surface water. The largest total withdrawals generally occurred in eastern Arkansas and in counties along major rivers (figs. 1, 2 , and 4). The five counties with the largest total water use are Pope (987.15 Mgal/d), Arkansas (939.73 Mgal/d), Poinsett (937.26 Mgal/d), Cross (561.71 Mgal/d), and Lonoke (489.49 Mgal/d) (table 1). The largest groundwater withdrawals were in eastern Arkansas (fig. 4). The five counties with the largest groundwater withdrawals were Poinsett (845.82 Mgal/d), Arkansas (540.08 Mgal/d), Cross (523.74 Mgal/d), Jackson (419.50 Mgal/d), and Clay (399.81 Mgal/d) (table 1). The largest surface-water withdrawals were from the Arkansas and White Rivers and Beaver Lake (fig. 2). The five counties with the largest surfacewater withdrawals were Pope (985.45 Mgal/day), Arkansas (399.65 Mgal/day), Benton (396.78 Mgal/day), Hot Spring (124.57 Mgal/d), and Lonoke (123.70 Mgal/d) (table 1).

The distribution of total water, groundwater, and surfacewater uses by category illustrates the dominance of the irrigation water-use category in Arkansas (fig. 5). Irrigation was the dominant category of groundwater use in Arkansas, almost 41 times greater than the second largest user of groundwater, aquaculture. Thermoelectric power generation, followed closely by irrigation, was the dominant category of surfacewater use in Arkansas.

\section{Public Supply}

Public supply refers to water withdrawn by public and private water suppliers and delivered to multiple users for domestic, commercial, industrial, and thermoelectric power generation uses. Public supply includes public and private systems that furnish water to at least 25 people or have a minimum of 15 service connections.

Data on public-supply withdrawals are obtained from ANRC water-use registration reports. The ANRC requires all public and private suppliers in Arkansas to submit annual and monthly withdrawals and deliveries. Site-specific data for about 800 public water suppliers are stored in the WUDBS maintained by USGS. Data reporting deficiencies are supplemented with information from monthly operation reports submitted to the Arkansas Department of Health (ADH). Population served, source of water, facilities sold to, and amounts purchased from other public suppliers are available on the ADH Web site (Arkansas Department of Health, 2011).

Public-supply systems served about 2.77 million of the 2.96 million Arkansans or about 95 percent of Arkansas' population in 2010. Public-supply total withdrawals in 2010 for Arkansas were $429 \mathrm{Mgal} / \mathrm{d}$ (fig. 5, table 2); about 69 percent was from surface-water sources. Public-supply withdrawals accounted for 3.8 percent of the total withdrawals of water in the State for all purposes. Groundwater withdrawals for public supply were $134 \mathrm{Mgal} / \mathrm{d}$ or about 1.7 percent of the State's total groundwater withdrawals for 2010. Public-supply surfacewater withdrawals were about $295 \mathrm{Mgal} / \mathrm{d}$ or about 8.3 percent of the State's total surface-water withdrawals.

Benton County had the largest total withdrawals for public supply in 2010 at $66.01 \mathrm{Mgal} / \mathrm{d}$, serving 221,339 users. Most of Benton County's withdrawals for public supply were from surface water (Beaver Lake), $61.39 \mathrm{Mgal} / \mathrm{d}$, also making Benton County the largest withdrawer of surface water for public supply. Pulaski County had the second largest surfacewater withdrawals for public supply (Lakes Maumelle and Winona) in 2010 at $46.75 \mathrm{Mgal} / \mathrm{d}$, serving 376,699 users. Craighead County had the largest groundwater withdrawals for public supply in 2010 at $15.27 \mathrm{Mgal} / \mathrm{d}$, serving 91,509 users. Jefferson County had the second largest groundwater withdrawals for public supply in 2010 at $13.14 \mathrm{Mgal} / \mathrm{d}$, serving 77,060 users.

Per capita residential water use for public-supply systems was calculated by dividing the amount of water withdrawn per day by the population served, providing per capita water use in gallons per day (gal/d). The 2010 statewide average of per capita residential use from public-supply systems was about $155 \mathrm{gal} / \mathrm{d}$. Conway County had the highest per capita use at $680 \mathrm{gal} / \mathrm{d}$.

\section{Domestic (Self-Supplied)}

Domestic water use includes water for household purposes, such as drinking, food preparation, bathing, washing clothes and dishes, flushing toilets, and watering lawns and gardens. Most water used for domestic purposes in Arkansas is provided by public supply. However, about 144,000 people in Arkansas (or about 5 percent of the State's population) (U.S. Department of Commerce, U.S. Census Bureau, 2010, Census 2010 summary files [SF1]) supply their own water from individual wells; these users are considered self-supplied. All domestic (self-supplied) withdrawals were assumed to be obtained from groundwater sources.

The domestic (self-supplied) water use in Arkansas for 2010 was 12.8 Mgal/d (table 3). Domestic (self-supplied) withdrawals account for about 0.1 percent of the total withdrawals of water or about 0.2 percent of total groundwater withdrawals in the State for all purposes. Miller County had the largest withdrawals for domestic (self-supplied) with $0.75 \mathrm{Mgal} / \mathrm{d}$. Baxter and Pope Counties had the second largest withdrawals for domestic (self-supplied) with each withdrawing about $0.73 \mathrm{Mgal} / \mathrm{d}$. The statewide average for per capita domestic (self-supplied) water use was about 89 gal/d. Newton and St Francis Counties had the highest per capita use of domestic (self-supplied) water use at $98 \mathrm{gal} / \mathrm{d}$. 
Table 1. Groundwater, surface-water, and total water withdrawals by county for Arkansas, 2010.

[Mgal/d, million gallons per day; values may not sum to totals because of independent rounding]

\begin{tabular}{|c|c|c|c|c|c|c|c|}
\hline County & $\begin{array}{l}\text { Ground- } \\
\text { water } \\
\text { (Mgal/d) }\end{array}$ & $\begin{array}{c}\text { Surface } \\
\text { water } \\
\text { (Mgal/d) }\end{array}$ & $\begin{array}{c}\text { Total } \\
\text { water } \\
\text { (Mgal/d) }\end{array}$ & County & $\begin{array}{l}\text { Ground- } \\
\text { water } \\
\text { (Mgal/d) }\end{array}$ & $\begin{array}{c}\text { Surface } \\
\text { water } \\
\text { (Mgal/d) }\end{array}$ & $\begin{array}{c}\text { Total } \\
\text { water } \\
(\text { Mgal/d) }\end{array}$ \\
\hline Arkansas & 540.08 & 399.65 & 939.73 & Lee & 300.75 & 6.25 & 307.00 \\
\hline Ashley & 139.18 & 65.97 & 205.15 & Lincoln & 197.41 & 26.78 & 224.19 \\
\hline Baxter & 1.37 & 3.47 & 4.84 & Little River & 4.02 & 101.16 & 105.18 \\
\hline Bradley & 1.98 & 0.09 & 2.07 & Madison & 0.93 & 0.84 & 1.77 \\
\hline Calhoun & 0.63 & 0.02 & 0.65 & Marion & 0.84 & 1.19 & 2.03 \\
\hline Carroll & 1.77 & 8.94 & 10.71 & Miller & 6.85 & 8.67 & 15.52 \\
\hline Chicot & 203.61 & 69.44 & 273.05 & Mississippi & 373.53 & 7.65 & 381.18 \\
\hline Cleveland & 1.16 & 0.27 & 1.43 & Newton & 1.15 & 0.21 & 1.36 \\
\hline Columbia & 9.47 & 1.78 & 11.25 & Ouachita & 1.24 & 42.20 & 43.44 \\
\hline Conway & 1.66 & 27.50 & 29.16 & Perry & 0.49 & 1.53 & 2.02 \\
\hline Craighead & 372.58 & 50.15 & 422.73 & Phillips & 264.81 & 1.85 & 266.66 \\
\hline Crawford & 0.87 & 33.86 & 34.73 & Pike & 0.65 & 1.19 & 1.84 \\
\hline Crittenden & 218.21 & 1.53 & 219.74 & Poinsett & 845.82 & 91.44 & 937.26 \\
\hline Cross & 523.74 & 37.97 & 561.71 & Polk & 1.15 & 2.80 & 3.95 \\
\hline Dallas & 0.78 & 0.02 & 0.80 & Pope & 1.70 & 985.45 & 987.15 \\
\hline Grant & 5.12 & 0.20 & 5.32 & Searcy & 1.54 & 0.27 & 1.81 \\
\hline Greene & 356.37 & 10.61 & 366.98 & Sebastian & 0.24 & 3.50 & 3.74 \\
\hline Hempstead & 3.41 & 1.25 & 4.66 & Sevier & 0.95 & 3.63 & 4.58 \\
\hline Hot Spring & 0.44 & 124.57 & 125.01 & Sharp & 1.39 & 2.11 & 3.50 \\
\hline Howard & 0.54 & 3.89 & 4.43 & Stone & 0.67 & 2.12 & 2.79 \\
\hline Independence & 58.67 & 98.03 & 156.70 & Union & 7.64 & 12.78 & 20.42 \\
\hline Izard & 1.30 & 3.34 & 4.64 & Van Buren & 0.25 & 4.10 & 4.35 \\
\hline Jackson & 419.50 & 22.48 & 441.98 & Washington & 1.09 & 1.98 & 3.07 \\
\hline Jefferson & 279.54 & 71.09 & 350.63 & White & 32.56 & 55.47 & 88.03 \\
\hline Johnson & 0.35 & 5.22 & 5.57 & Woodruff & 215.36 & 30.96 & 246.32 \\
\hline Lafayette & 24.04 & 1.08 & 25.12 & Yell & 0.45 & 3.68 & 4.13 \\
\hline Lawrence & 179.91 & 18.63 & 198.54 & Totals: & 7,790 & 3,540 & 11,300 \\
\hline
\end{tabular}




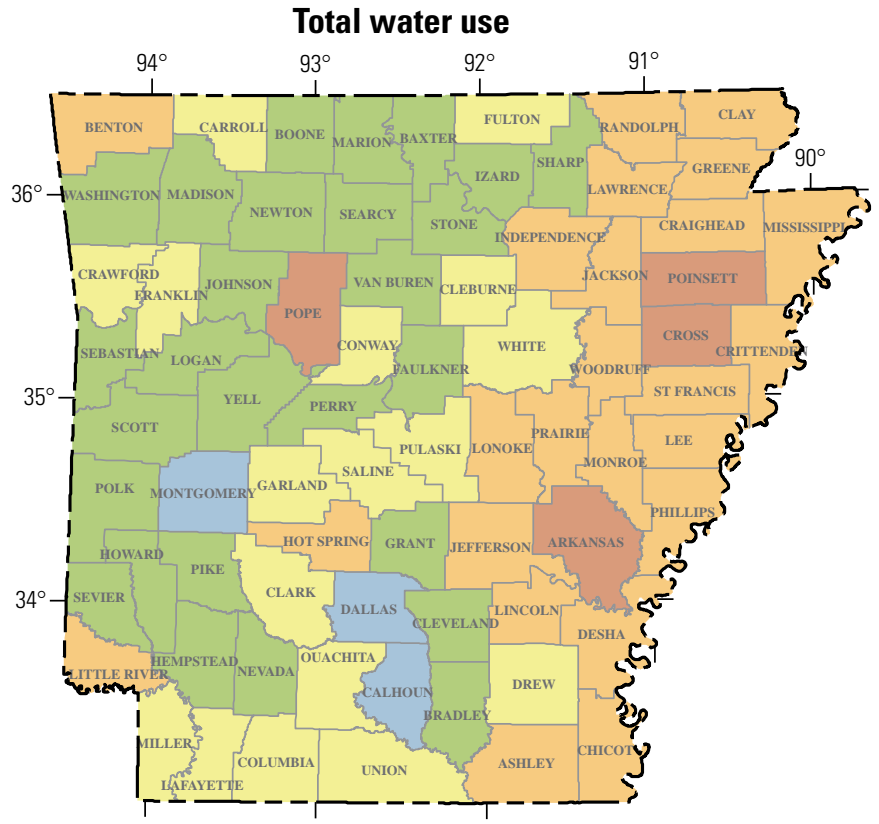

Base from the U.S. Geological Survey digital data, 1:000,000 Universal Transverse Mercator projection Zone 15

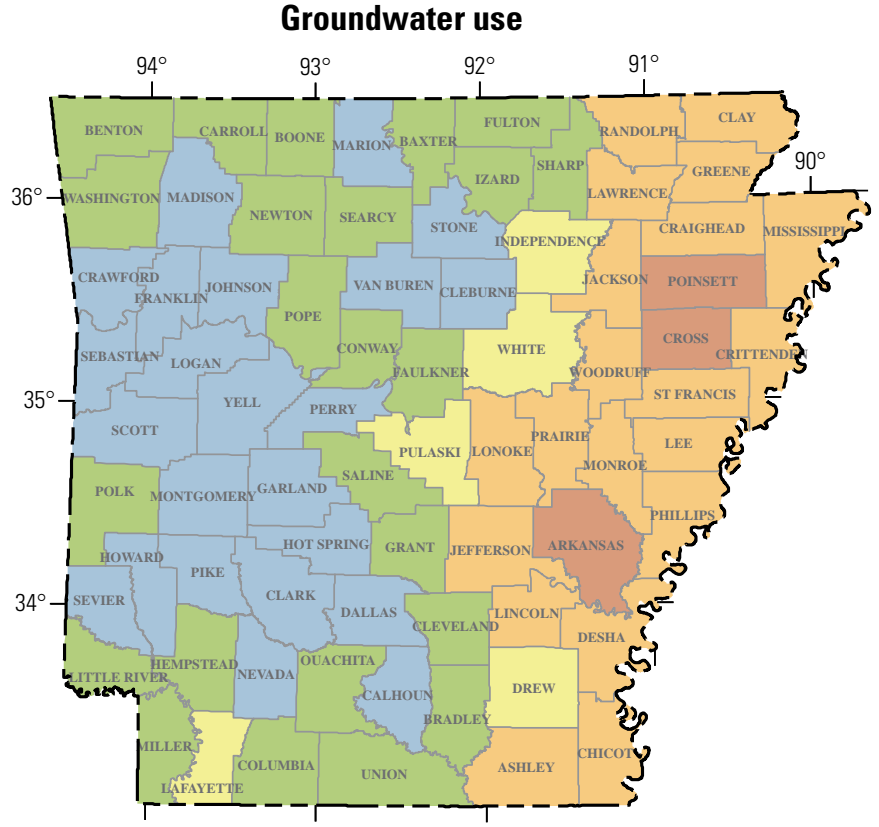

Base from the U.S. Geological Survey digital data, 1:000,000 Universal Transverse Mercator projection Zone 15

\section{EXPLANATION}

Water use, in million gallons per day
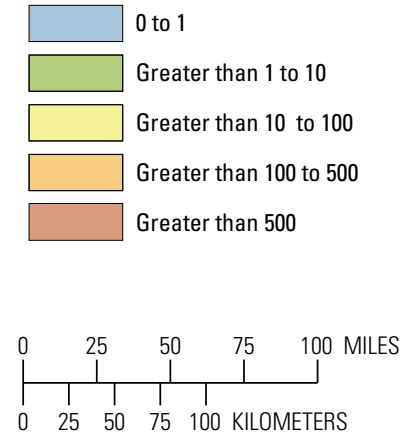

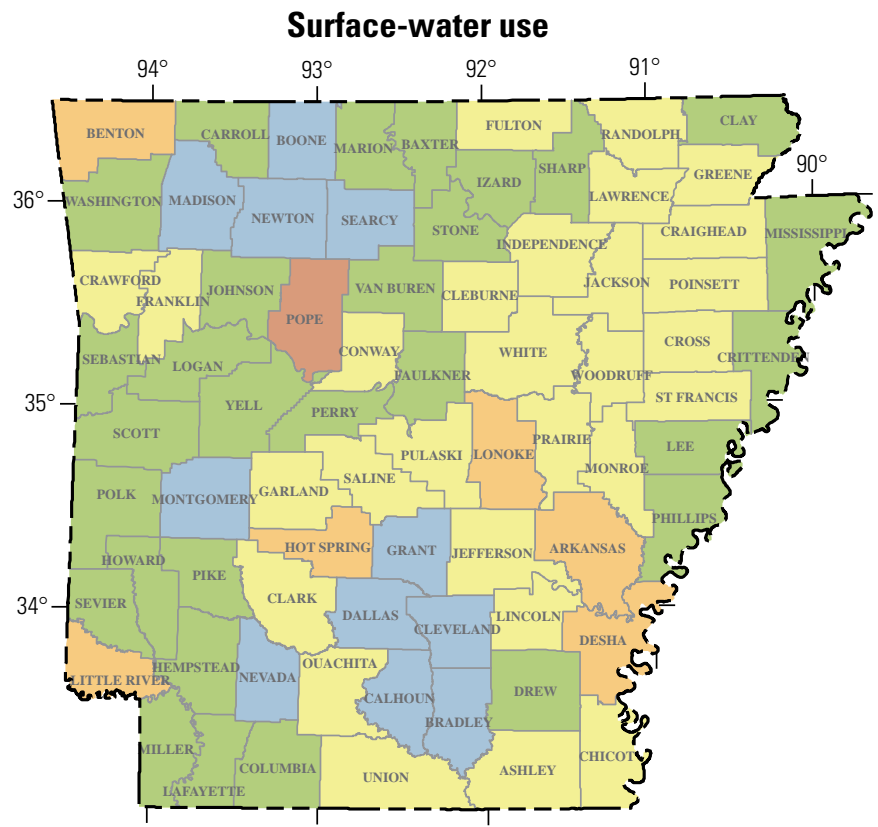

Base from the U.S. Geological Survey digital data, 1:000,000 Universal Transverse Mercator projection Zone 15

Figure 4. Total water, groundwater, and surface-water use by county for Arkansas, 2010. 


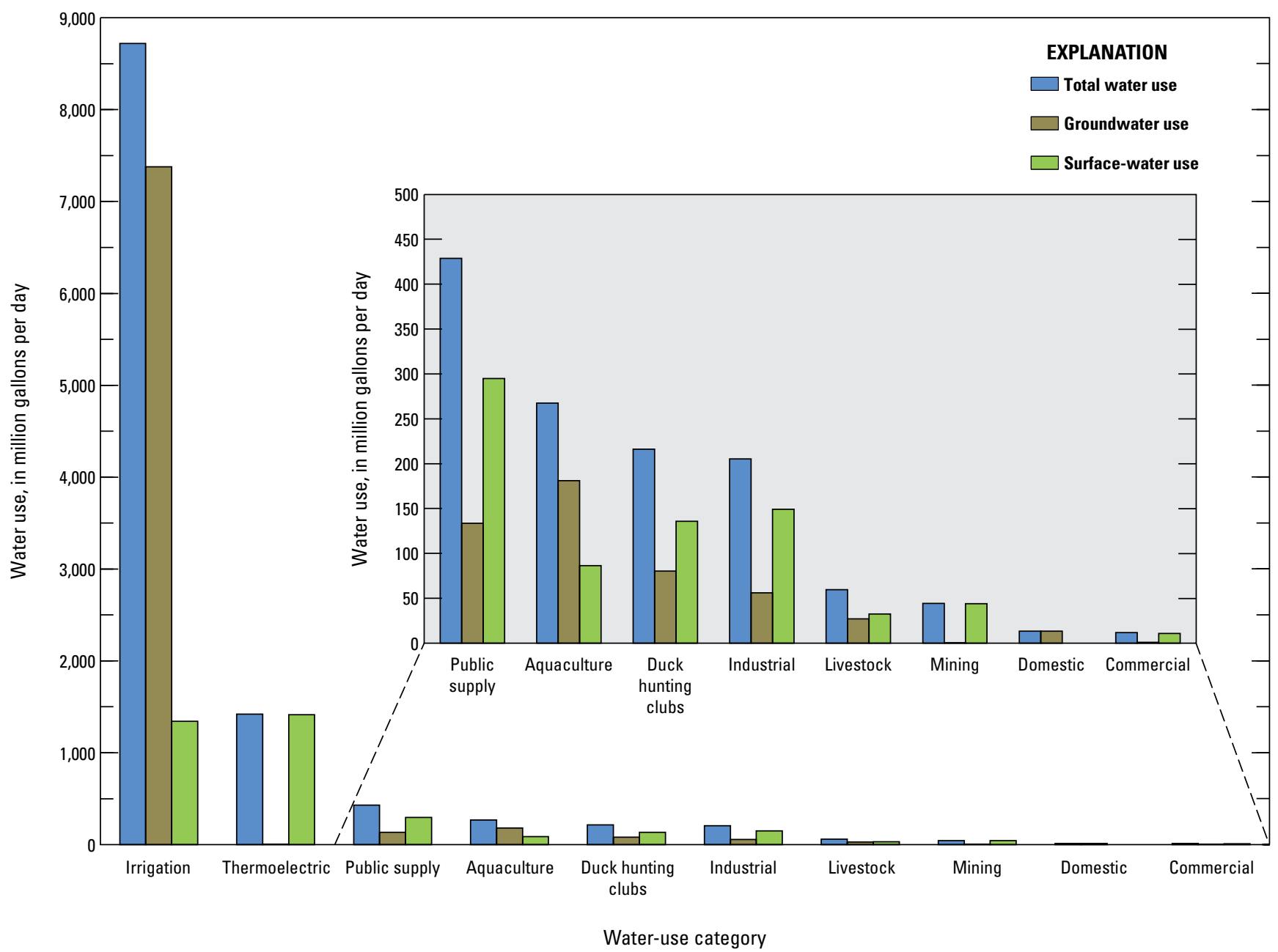

Figure 5. Total water, groundwater, and surface-water use in Arkansas by category, 2010. 


\section{Estimated Water Use in Arkansas, 2010}

Table 2. Public supply and per capita water use in Arkansas, 2010.

[Mgal/d, million gallons per day; gal/d, gallons per day; values may not sum to totals because of independent rounding]

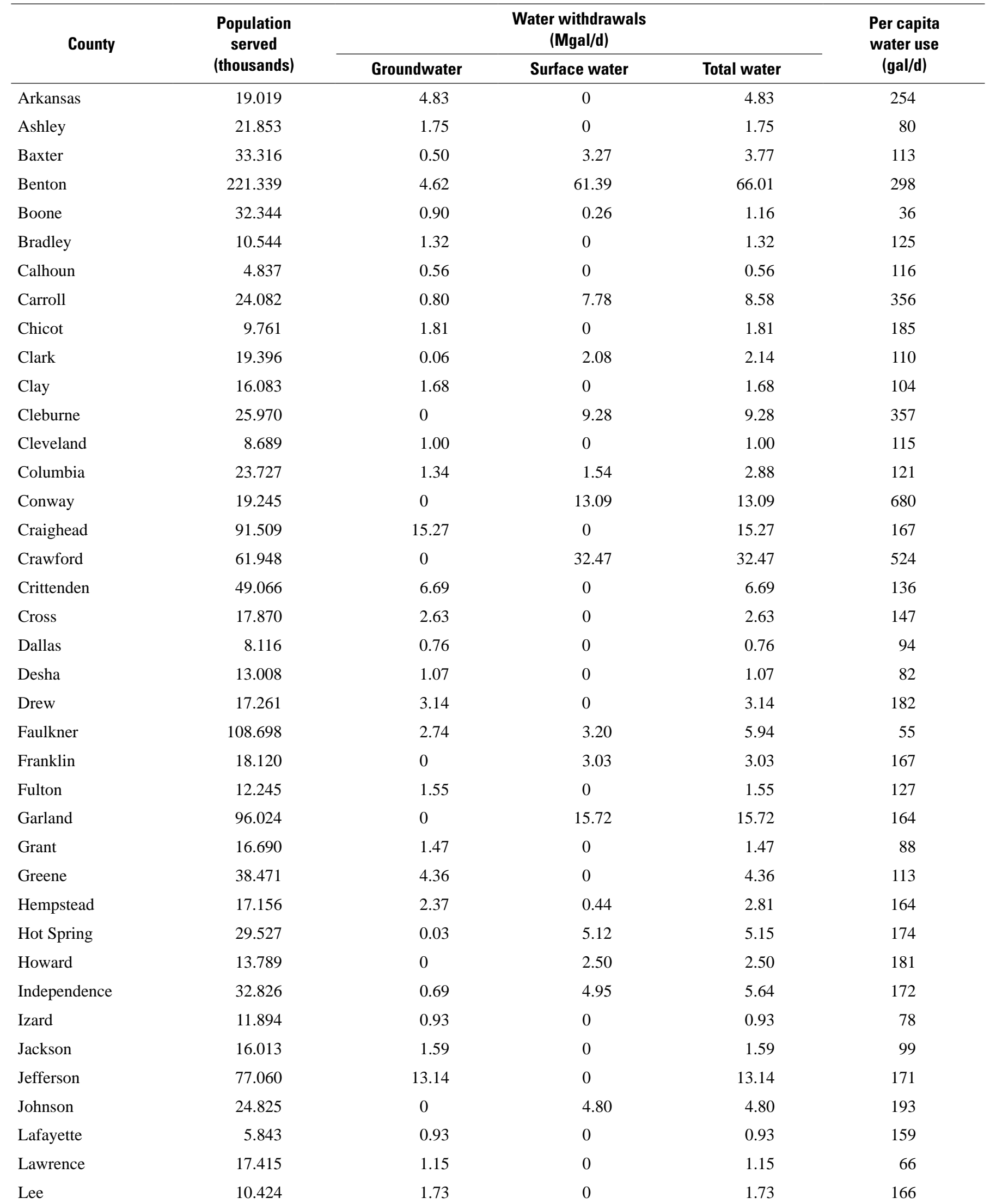


Table 2. Public supply and per capita water use in Arkansas, 2010.-Continued

[Mgal/d, million gallons per day; gal/d, gallons per day; values may not sum to totals because of independent rounding]

\begin{tabular}{|c|c|c|c|c|c|}
\hline \multirow[t]{2}{*}{ County } & \multirow{2}{*}{$\begin{array}{l}\text { Population } \\
\text { served } \\
\text { (thousands) }\end{array}$} & \multicolumn{3}{|c|}{$\begin{array}{l}\text { Water withdrawals } \\
\text { (Mgal/d) }\end{array}$} & \multirow{2}{*}{$\begin{array}{c}\text { Per capita } \\
\text { water use } \\
\text { (gal/d) }\end{array}$} \\
\hline & & Groundwater & Surface water & Total water & \\
\hline Lincoln & 14.134 & 1.48 & 0 & 1.48 & 105 \\
\hline Little River & 13.171 & 0.56 & 2.73 & 3.29 & 250 \\
\hline Logan & 22.353 & 0 & 2.79 & 2.79 & 125 \\
\hline Lonoke & 68.356 & 7.27 & 0 & 7.27 & 106 \\
\hline Madison & 11.331 & 0 & 0 & 0 & 0 \\
\hline Marion & 9.182 & 0 & 0.93 & 0.93 & 101 \\
\hline Miller & 35.018 & 0.10 & 0 & 0.10 & 3 \\
\hline Mississippi & 45.198 & 7.19 & 0 & 7.19 & 159 \\
\hline Monroe & 7.630 & 1.33 & 0 & 1.33 & 174 \\
\hline Montgomery & 9.008 & 0 & 0.57 & 0.57 & 63 \\
\hline Nevada & 6.908 & 0.09 & 0.69 & 0.78 & 113 \\
\hline Newton & 7.821 & 0.97 & 0 & 0.97 & 124 \\
\hline Ouachita & 26.120 & 1.16 & 2.59 & 3.75 & 144 \\
\hline Perry & 6.431 & 0.01 & 0.91 & 0.92 & 143 \\
\hline Phillips & 21.757 & 3.17 & 0 & 3.17 & 146 \\
\hline Pike & 8.423 & 0.05 & 0.69 & 0.74 & 88 \\
\hline Poinsett & 22.755 & 2.86 & 0 & 2.86 & 126 \\
\hline Polk & 13.198 & 0 & 1.67 & 1.67 & 127 \\
\hline Pope & 53.580 & 0 & 11.17 & 11.17 & 208 \\
\hline Prairie & 7.113 & 0.77 & 0 & 0.77 & 108 \\
\hline Pulaski & 376.699 & 3.72 & 46.75 & 50.47 & 134 \\
\hline Randolph & 13.010 & 0.11 & 1.03 & 1.14 & 88 \\
\hline St Francis & 27.952 & 4.99 & 0 & 4.99 & 179 \\
\hline Saline & 107.118 & 4.50 & 26.9 & 31.40 & 293 \\
\hline Scott & 7.144 & 0 & 0.81 & 0.81 & 113 \\
\hline Searcy & 7.718 & 1.31 & 0 & 1.31 & 170 \\
\hline Sebastian & 125.744 & 0 & 2.96 & 2.96 & 24 \\
\hline Sevier & 13.758 & 0.29 & 3.07 & 3.36 & 244 \\
\hline Sharp & 13.239 & 0.78 & 1.73 & 2.51 & 190 \\
\hline Stone & 11.717 & 0.28 & 1.73 & 2.01 & 172 \\
\hline Union & 36.733 & 5.34 & 0 & 5.34 & 145 \\
\hline Van Buren & 16.029 & 0 & 2.01 & 2.01 & 125 \\
\hline Washington & 203.065 & 0 & 0.20 & 0.20 & 1 \\
\hline White & 77.076 & 0.04 & 9.09 & 9.13 & 118 \\
\hline Woodruff & 7.260 & 1.88 & 0 & 1.88 & 259 \\
\hline Yell & 21.732 & 0 & 3.07 & 3.07 & 141 \\
\hline Totals: & 2,770 & 134 & 295 & 429 & -- \\
\hline
\end{tabular}


Table 3. Domestic (self-supplied) water use in Arkansas, 2010.

[Mgal/d, million gallons per day; values may not sum to totals because of independent rounding]

\begin{tabular}{|c|c|c|c|c|c|c|c|}
\hline County & $\begin{array}{c}\text { Self-supplied } \\
\text { population } \\
\text { (thousands) }\end{array}$ & $\begin{array}{c}\text { Domestic } \\
\text { use } \\
\text { (Mgal/d) }\end{array}$ & $\begin{array}{c}\text { Per capita } \\
\text { use } \\
\text { (Mgal/d) }\end{array}$ & County & $\begin{array}{c}\text { Self-supplied } \\
\text { population } \\
\text { (thousands) }\end{array}$ & $\begin{array}{c}\text { Domestic } \\
\text { use } \\
\text { (Mgal/d) }\end{array}$ & $\begin{array}{c}\text { Per capita } \\
\text { use } \\
\text { (Mgal/d) }\end{array}$ \\
\hline Arkansas & 0 & 0 & 0 & Lincoln & 0 & 0 & 0 \\
\hline Ashley & 0 & 0 & 0 & Little River & 0 & 0 & 0 \\
\hline Baxter & 8.20 & 0.73 & 89 & Logan & 0 & 0 & 0 \\
\hline Bradley & 0.96 & 0.09 & 93 & Marion & 7.47 & 0.67 & 90 \\
\hline Calhoun & 0.53 & 0.05 & 94 & Miller & 8.44 & 0.75 & 89 \\
\hline Carroll & 3.36 & 0.30 & 89 & Mississippi & 1.28 & 0.11 & 86 \\
\hline Chicot & 2.04 & 0.18 & 88 & Monroe & 0.52 & 0.05 & 96 \\
\hline Cleveland & 0 & 0 & 0 & Ouachita & 0 & 0 & 0 \\
\hline Columbia & 0.83 & 0.07 & 85 & Perry & 4.01 & 0.36 & 90 \\
\hline Conway & 2.03 & 0.18 & 89 & Phillips & 0 & 0 & 0 \\
\hline Craighead & 4.93 & 0.44 & 89 & Pike & 2.87 & 0.26 & 91 \\
\hline Crawford & 0 & 0 & 0 & Poinsett & 1.83 & 0.16 & 88 \\
\hline Crittenden & 1.84 & 0.16 & 87 & Polk & 7.46 & 0.66 & 88 \\
\hline Cross & 0 & 0 & 0 & Pope & 8.17 & 0.73 & 89 \\
\hline Dallas & 0 & 0 & 0 & Prairie & 1.60 & 0.14 & 87 \\
\hline Garland & 0 & 0 & 0 & Searcy & 0.48 & 0.04 & 84 \\
\hline Grant & 1.16 & 0.10 & 86 & Sebastian & 0 & 0 & 0 \\
\hline Greene & 3.62 & 0.32 & 88 & Sevier & 3.30 & 0.29 & 88 \\
\hline Hempstead & 5.45 & 0.49 & 90 & Sharp & 4.03 & 0.36 & 89 \\
\hline Hot Spring & 3.40 & 0.30 & 88 & Stone & 0.68 & 0.06 & 89 \\
\hline Howard & 0 & 0 & 0 & Union & 4.91 & 0.43 & 88 \\
\hline Independence & 3.82 & 0.34 & 89 & Van Buren & 1.27 & 0.11 & 87 \\
\hline Izard & 1.80 & 0.16 & 89 & Washington & 0 & 0 & 0 \\
\hline Jackson & 1.98 & 0.18 & 91 & White & 0 & 0 & 0 \\
\hline Jefferson & 0.38 & 0.03 & 80 & Woodruff & 0 & 0 & 0 \\
\hline Johnson & 0.72 & 0.06 & 84 & Yell & 0.45 & 0.04 & 88 \\
\hline Lafayette & 1.80 & 0.16 & 89 & Totals: & 144 & 12.8 & -- \\
\hline Lawrence & 0 & 0 & 0 & \multirow{2}{*}{\multicolumn{3}{|c|}{$\begin{array}{r}\text { Statewide average per capita domestic } \\
\text { (self-supplied) water use: }\end{array}$}} & 89 \\
\hline Lee & 0 & 0 & 0 & & & & \\
\hline
\end{tabular}




\section{Commercial (Self-Supplied)}

Commercial (self-supplied) water use includes water for motels, hotels, restaurants, office buildings, schools, and civilian and military institutions. Estimates of water supplied by public-supply facilities to commercial users were obtained from data reported to the ANRC by public-supply facilities.

Total commercial (self-supplied) water use in Arkansas for 2010 was $11.7 \mathrm{Mgal} / \mathrm{d}$, with about 8 percent $(0.95 \mathrm{Mgal} / \mathrm{d})$ from groundwater sources and about 92 percent (10.8 Mgal/d) from surface-water sources (table 4). The largest commercial (self-supplied) use of water occurred in Hempstead County at $4.82 \mathrm{Mgal} / \mathrm{d}$ of which 100 percent was from a surfacewater source. The largest commercial (self-supplied) use of groundwater (alluvial aquifer) was in Poinsett County at $0.48 \mathrm{Mgal} / \mathrm{d}$.

\section{Industrial (Self-Supplied)}

Industrial (self-supplied) water use includes water for such purposes as fabrication, processing, washing, and cooling in facilities that manufacture products. Estimates of water supplied by public-supply systems to industrial users were obtained from data reported to the ANRC by the public-supply facilities.

Total industrial (self-supplied) water use in Arkansas for 2010 was $276 \mathrm{Mgal} / \mathrm{d}$, with about 22 percent (61.2 Mgal/d) from groundwater and about 78 percent (214 Mgal/d) from surface-water sources (table 5). The largest total use of industrial (self-supplied) water occurred in Little River County at $91.73 \mathrm{Mgal} / \mathrm{d}$. The largest industrial (self-supplied) use of surface water occurred in Little River County at 91.73 $\mathrm{Mgal} / \mathrm{d}$, and the largest industrial (self-supplied) use of groundwater (Sparta aquifer) occurred in Jefferson County at 35.35 Mgal/d).

\section{Mining}

Mining water use includes, in part, water used for coal, sand, and gravel washing operations, and saline withdrawals from oil and natural gas production wells. Total mining water use in Arkansas for 2010 was $44.3 \mathrm{Mgal} / \mathrm{d}$, with less than 1 percent (0.18 Mgal/d) from groundwater and over 99 percent (44.1 Mgal/d) from surface-water sources (table 6). The largest use of mining water (natural gas production wells) occurred in White County at $19.79 \mathrm{Mgal} / \mathrm{d}$ of which 100 percent was from surface-water sources. Cleburne County was the second largest user of mining water (natural gas production wells) at $15.94 \mathrm{Mgal} / \mathrm{d}$, also 100 percent from surface-water sources.
The largest mining use of groundwater (shale pits and stone quarries) occurred in Polk County at 0.07 Mgal/d.

\section{Livestock}

Livestock water use includes water used for stock watering, feed lots, dairy farming, and other farm needs. Water users that report their usage of water for livestock represent a small portion of the livestock water users in the State. Many livestock water users fall below the ANRC threshold for reporting groundwater or surface water. Consequently, the majority of the water volumes reported for livestock water use was estimated based on county livestock populations and the appropriate water requirement for each type of livestock. County livestock populations for Arkansas were obtained from published data from the U.S. Department of Agriculture, National Agricultural Statistics Service Web site (for the year 2010). Water requirements are listed in table 7 (Holland, 1987). Livestock populations were multiplied by the appropriate water requirements to obtain livestock water-use estimates.

Total livestock water use in Arkansas for 2010 was 39.0 Mgal/d, with about 40 percent (15.6 Mgal/d) from groundwater and about 60 percent (23.4 Mgal/d) from surfacewater sources (table 8). Consumptive use for livestock is considered to be 100 percent of withdrawals. The largest water use for livestock was in Washington County at 2.72 Mgal/d. Washington County was the largest user of groundwater for livestock at $1.09 \mathrm{Mgal} / \mathrm{d}$ and also the largest surface-water user for livestock at $1.63 \mathrm{Mgal} / \mathrm{d}$. Benton County was the second largest user of water for livestock at $2.58 \mathrm{Mgal} / \mathrm{d}$ total water, 0.99 Mgal/d from groundwater, and 1.59 Mgal/d from surface-water sources.

\section{Aquaculture}

Aquaculture water use includes water used for farming of organisms that live in water, such as fish, shellfish, and algae. Total aquaculture water use in Arkansas for 2010 was $268 \mathrm{Mgal} / \mathrm{d}$, of which about 68 percent (181 Mgal/d) was from groundwater and about 32 percent $(86.5 \mathrm{Mgal} / \mathrm{d})$ was from surface-water sources (table 9). The largest total use of aquaculture water was in Fulton County at 82.04 Mgal/d, with all from surface-water sources. The largest aquaculture use of groundwater was in Chicot County at $46.78 \mathrm{Mgal} / \mathrm{d}$. Other counties with notable aquaculture water use (greater than $25 \mathrm{Mgal} / \mathrm{d}$ ) were Lonoke (42.05 Mgal/d) and Prairie (29.18 Mgal/d). Reported water use for aquaculture does not include usage by government fish hatcheries. 
Table 4. Commercial (self-supplied) water use in Arkansas, 2010.

[Mgal/d, million gallons per day; values may not sum to totals because of independent rounding]

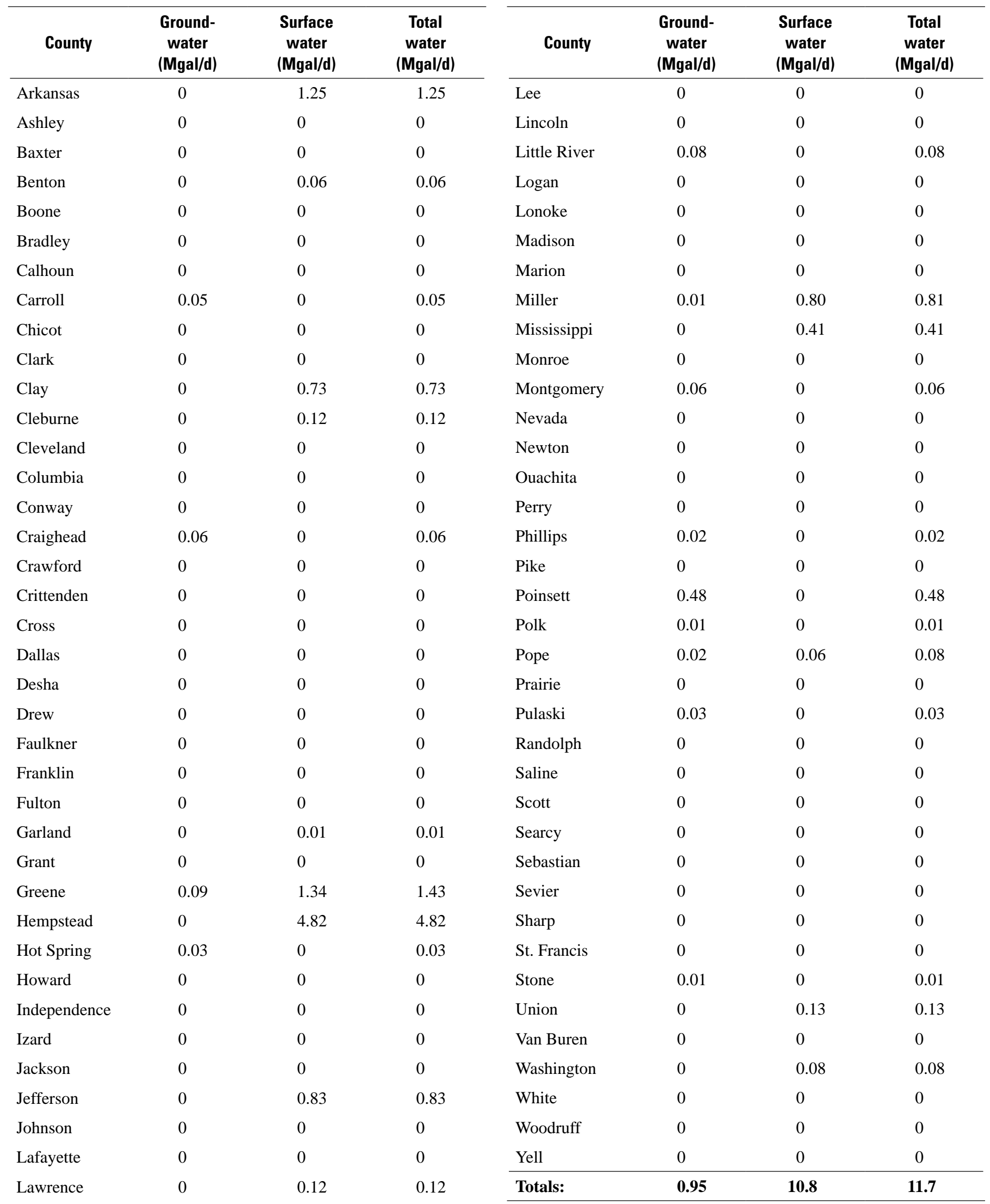


Table 5. Industrial (self-supplied) water use in Arkansas, 2010.

[Mgal/d, million gallons per day; values may not sum to totals because of independent rounding]

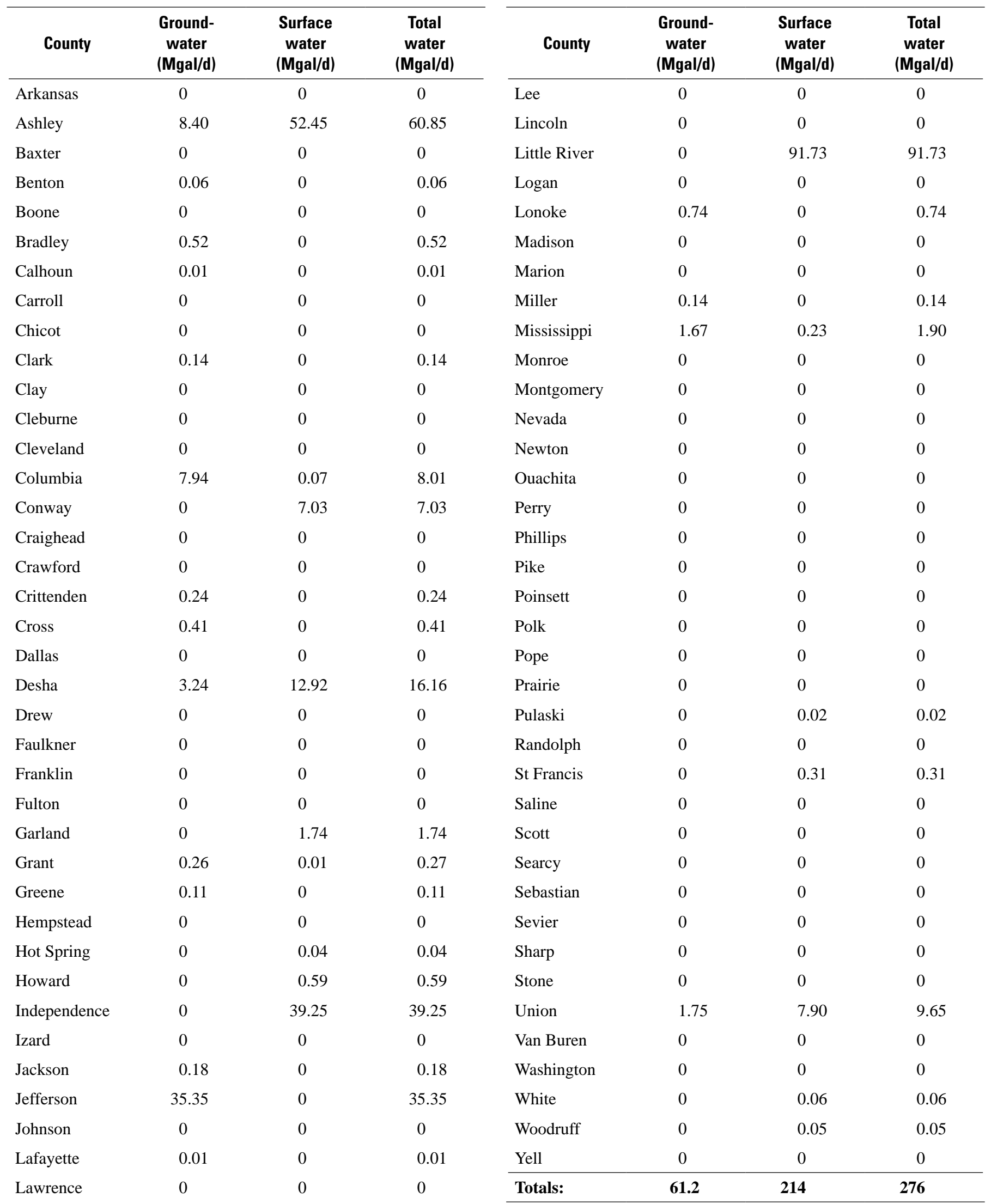


Table 6. Mining water use in Arkansas, 2010.

[Mgal/d, million gallons per day; values may not sum to totals because of independent rounding]

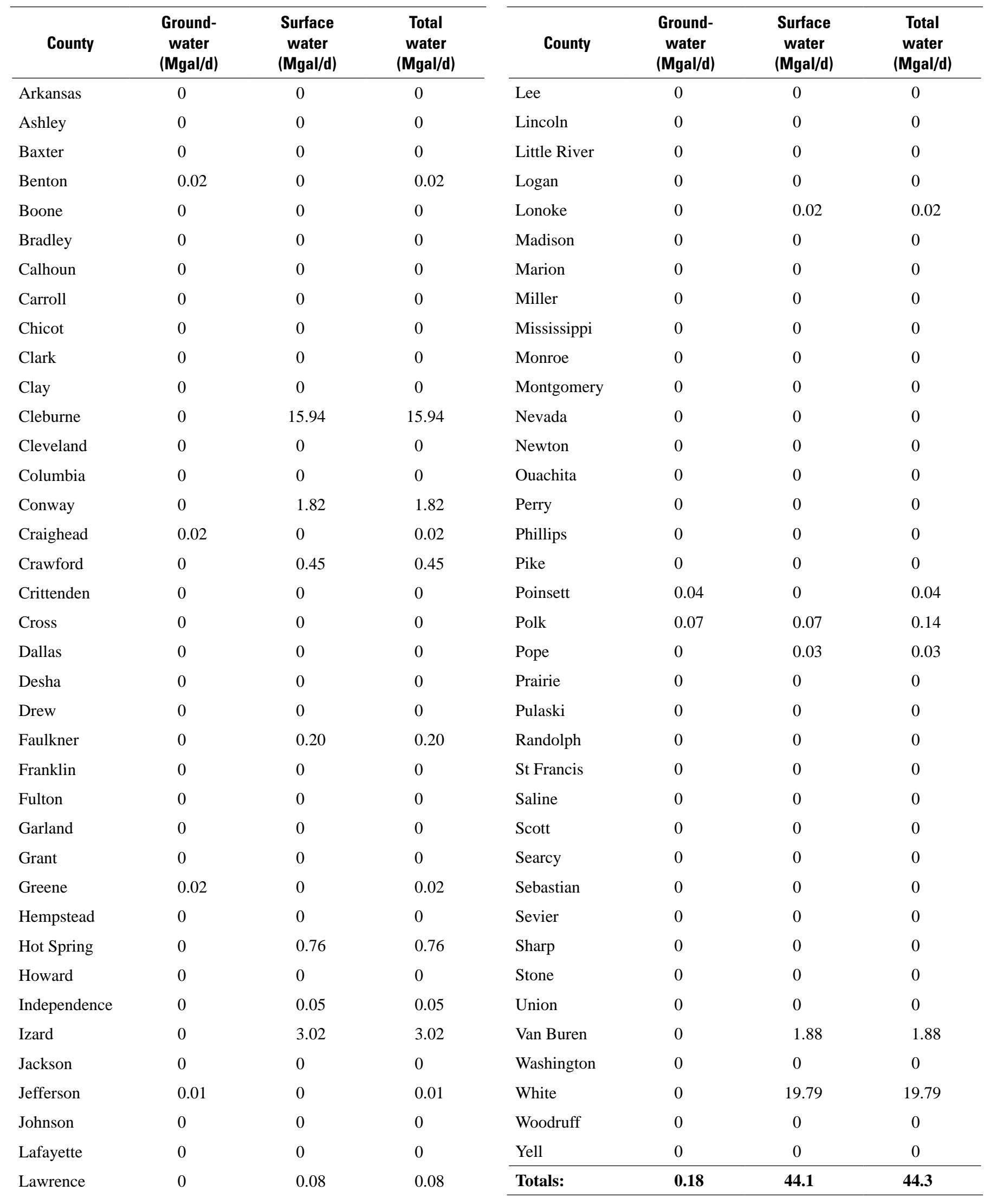


Table 7. Livestock water requirements.

[gal/d; gallons per day]

\begin{tabular}{lc}
\hline Livestock & $\begin{array}{c}\text { Water required per animal } \\
\text { (gal/d) }\end{array}$ \\
\hline Dairy cattle & 30 \\
Other cattle & 15 \\
Hogs & 2 \\
Poultry & \\
Broilers & 0.04 \\
Hens & 0.06 \\
Turkeys & 0.08 \\
\hline
\end{tabular}

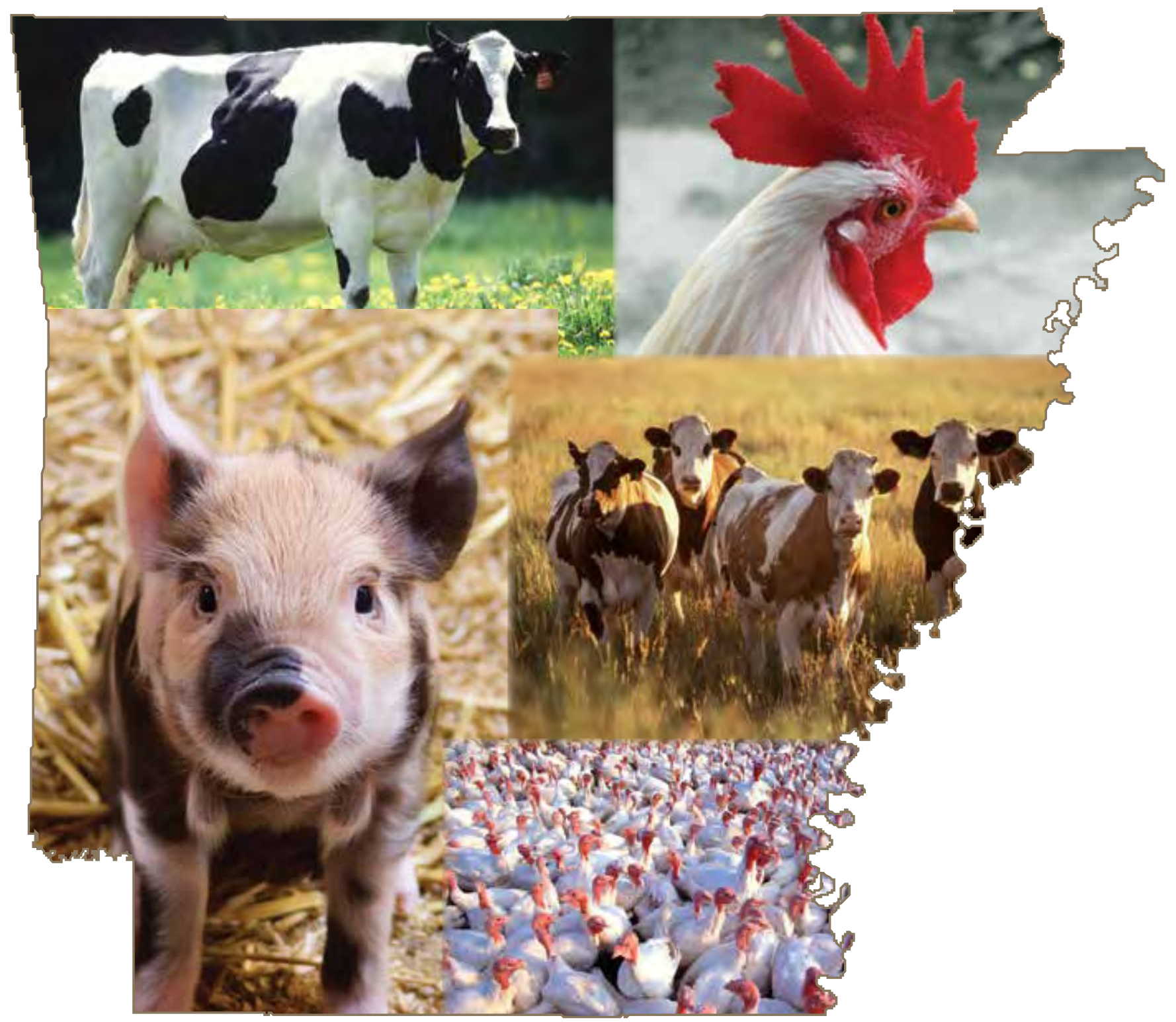


Table 8. Livestock water use in Arkansas, 2010.

[Mgal/d, million gallons per day; values may not sum to totals because of independent rounding]

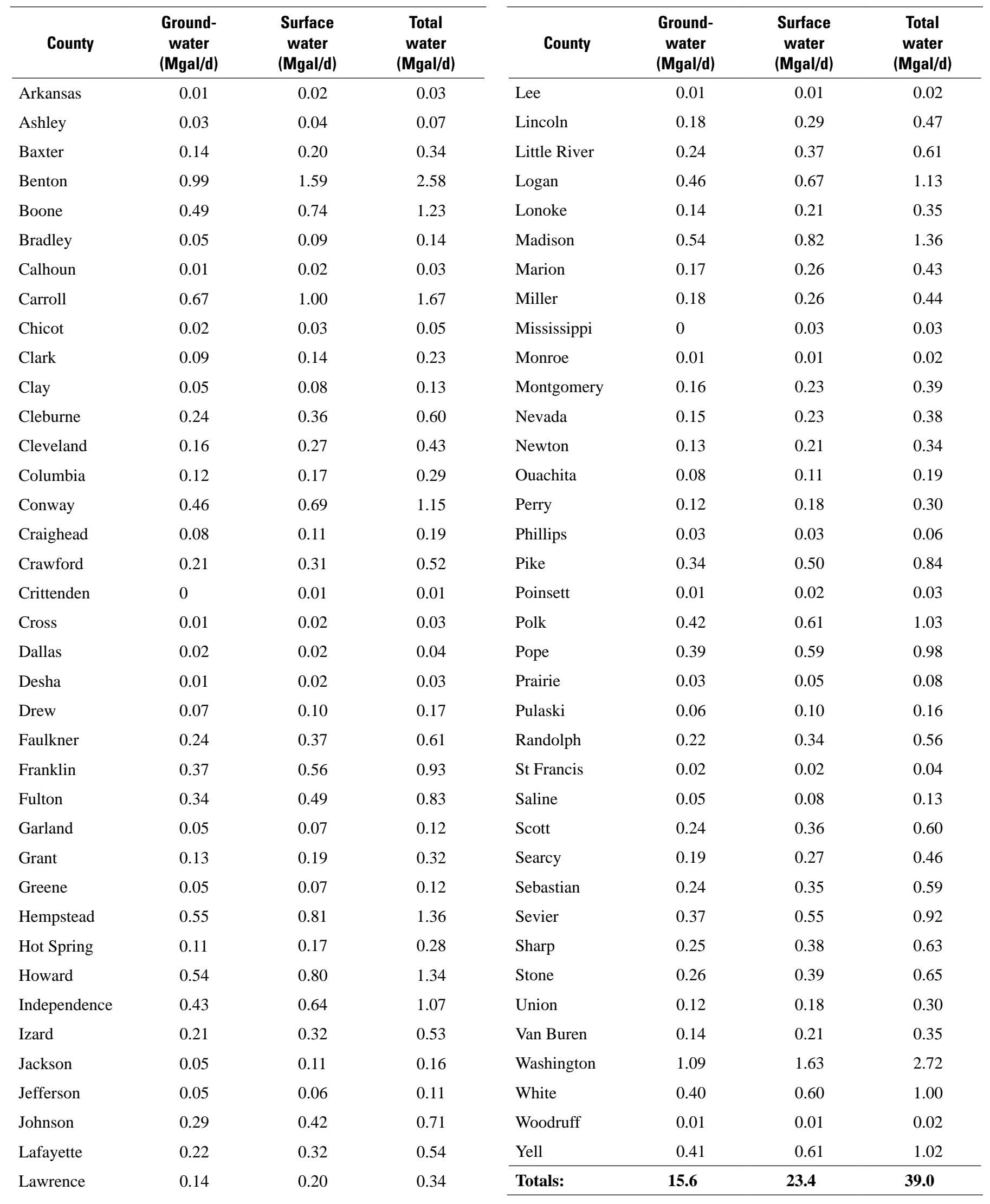


Table 9. Aquaculture water use in Arkansas, 2010.

[Mgal/d, million gallons per day; values may not sum to totals because of independent rounding; reported water-use for aquaculture does not include usage by grovrnment fish hatcheries]

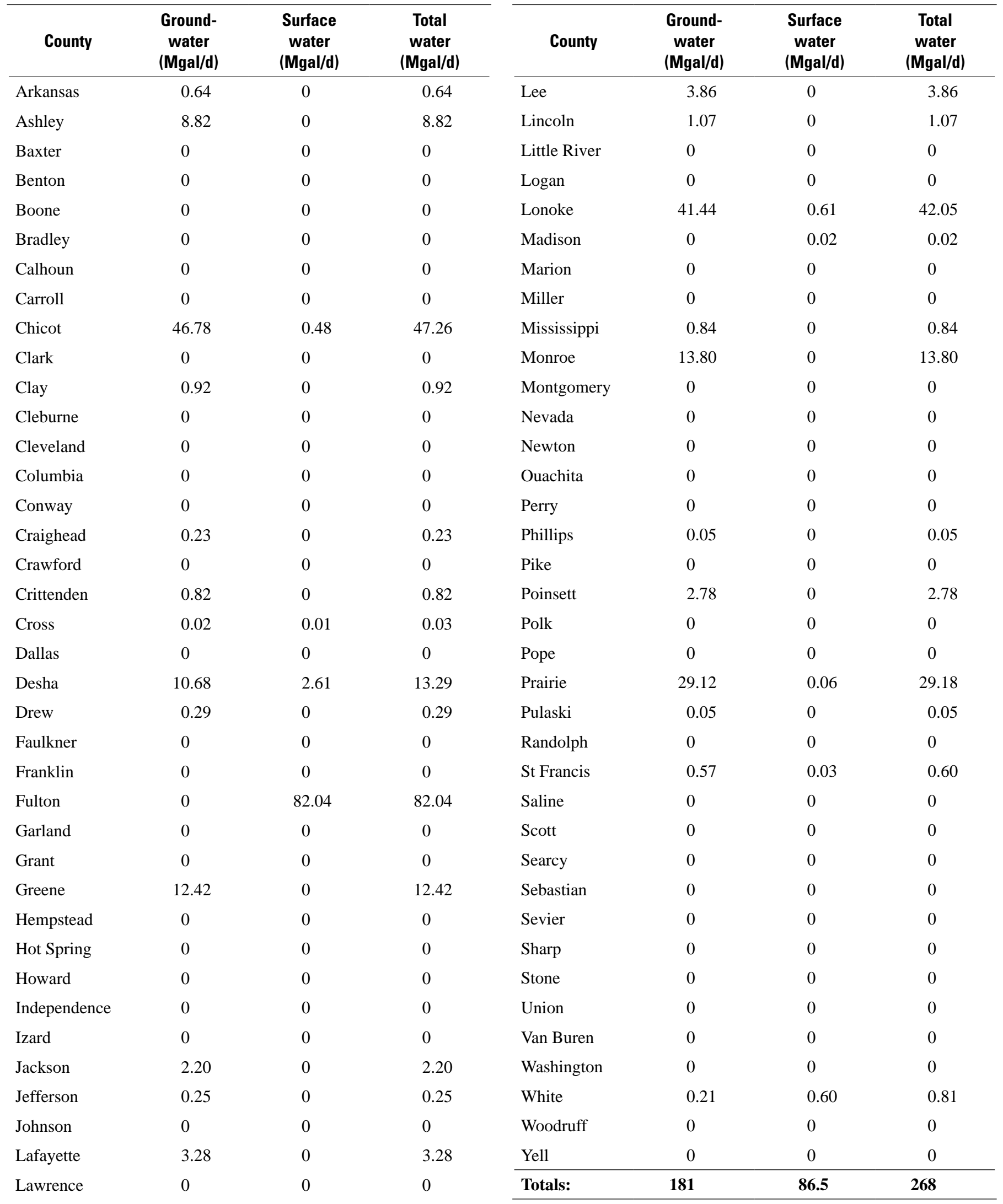




\section{Irrigation}

Irrigation water use includes water applied on lands to assist in the growing of crops and pastures or to maintain vegetative growth on recreational lands, such as parks and golf courses. The major crops irrigated in Arkansas (in descending order of reported water applied) were rice, soybeans, cotton, corn, and milo (table 10). During 2010, over 4.67 million acres of irrigated land were reported to ANRC. About 2.10 million acres, or 45 percent, of the reported total irrigated land was in soybeans, and about 1.70 million acres, or 36 percent, of the reported total irrigated land was in rice. Rice and soybeans had the largest amounts of reported water applied at 1,630,898 Mgal and 1,107,623 Mgal, respectively. Rice and corn had the largest application rates of water applied per acre at 0.9605 Mgal (2.95 acre-ft) and 0.5384 Mgal (1.65 acre-ft), respectively.

In 2010, surface irrigation (flood or furrow irrigation) greatly exceeded all other types of irrigation in Arkansas. Irrigation groundwater use accounted for about 95 percent of all groundwater withdrawn in Arkansas (tables 1 and 11). Irrigation water use totaled $8,720 \mathrm{Mgal} / \mathrm{d}$, with about 85 percent (7,380 Mgal/d) from groundwater and about 15 percent (1,340 Mgal/d) from surface-water sources (table 11). The largest user of water for irrigation was Arkansas County using 934.23 Mgal/d, with about 57 percent (534.60 Mgal/d) from groundwater and about 43 percent (399.63 Mgal/d) from surface-water sources. Other counties with notable total irrigation water use (greater than $400 \mathrm{Mgal} / \mathrm{d}$ ) were Poinsett, Cross, Desha, Lonoke, Jackson, Craighead, and Clay (in order of decreasing use).

\section{Duck (Hunting) Clubs}

Duck (hunting) clubs are associations of huntsmen who hunt for sport (Webster, 2015). Groundwater and surface water are applied to open fields or large bayous or ponds to attract migratory waterfowl for the purpose of hunting. Total water use for duck (hunting) clubs in Arkansas for 2010 was $216 \mathrm{Mgal} / \mathrm{d}$, with about 37 percent (80.4 Mgal/d) from groundwater and about 63 percent (136 Mgal/d) from surfacewater sources (table 12). The largest use of water for duck (hunting) clubs was in Arkansas County at $82.24 \mathrm{Mgal} / \mathrm{d}$, of which 28 percent (22.84 Mgal/d) was from groundwater sources and 72 percent (59.40 Mgal/d) was from surface-water sources. Other counties with notable duck hunting water use (greater than $10 \mathrm{Mgal} / \mathrm{d}$ ) were Miller, Monroe, Prairie, and Jefferson (in order of decreasing use).

Table 10. Water use by crop for Arkansas, 2010.

[Mgal, million gallons; values may not sum to totals because of independent rounding]

\begin{tabular}{|c|c|c|c|c|c|}
\hline \multirow{2}{*}{ Crop } & \multirow{2}{*}{$\begin{array}{c}\text { Reported } \\
\text { acres planted }\end{array}$} & \multicolumn{2}{|c|}{ Reported water applied } & \multicolumn{2}{|c|}{ Water applied per acre } \\
\hline & & Acre-feet & Mgal & Feet & Mgal \\
\hline Wheat & 10,511 & 2,299 & 749 & 0.22 & 0.0713 \\
\hline Sorghum & 7,437 & 11,876 & 3,870 & 1.60 & 0.5203 \\
\hline Corn for grain & 283,997 & 469,263 & 152,910 & 1.65 & 0.5384 \\
\hline Milo & 12,540 & 15,149 & 4,936 & 1.21 & 0.3936 \\
\hline Oats & 868 & 58 & 19 & 0.07 & 0.0216 \\
\hline Cash grains - not classified & 365 & 563 & 183 & 1.54 & 0.5022 \\
\hline Cotton & 510,254 & 779,174 & 253,895 & 1.53 & 0.4976 \\
\hline Tobacco & 53 & 80 & 26 & 1.50 & 0.4888 \\
\hline Barries & 137 & 168 & 55 & 1.22 & 0.3984 \\
\hline Grapes & 110 & 28 & 9 & 0.25 & 0.0829 \\
\hline Peanuts & 1,020 & 1,546 & 504 & 1.52 & 0.4939 \\
\hline Fruit \& nut trees & 674 & 730 & 238 & 1.08 & 0.3530 \\
\hline Crop maintenance & 33,657 & 58,138 & 18,944 & 1.73 & 0.5629 \\
\hline \multirow[t]{2}{*}{ Totals: } & $4,672,925$ & $9,765,234$ & $3,182,015$ & -- & -- \\
\hline & & \multicolumn{2}{|c|}{ Average water applied per acre: } & 2.09 & 0.6809 \\
\hline
\end{tabular}


Table 11. Irrigation water use in Arkansas, 2010.

[Mgal/d, million gallons per day; surface irrigation, flood or furrow irrigation; values may not sum to totals because of independent rounding]

\begin{tabular}{|c|c|c|c|c|c|c|c|}
\hline \multirow{2}{*}{ County } & \multicolumn{3}{|c|}{$\begin{array}{l}\text { Water withdrawals } \\
\text { (Mgal/d) }\end{array}$} & \multicolumn{4}{|c|}{$\begin{array}{c}\text { Irrigated land } \\
\text { (thousand acres) }\end{array}$} \\
\hline & $\begin{array}{c}\text { Ground- } \\
\text { water }\end{array}$ & $\begin{array}{c}\text { Surface } \\
\text { water }\end{array}$ & $\begin{array}{l}\text { Total } \\
\text { water }\end{array}$ & $\begin{array}{l}\text { Sprinkler } \\
\text { irrigation }\end{array}$ & $\begin{array}{l}\text { Micro- } \\
\text { irrigation }\end{array}$ & $\begin{array}{l}\text { Surface } \\
\text { irrigation }\end{array}$ & Total \\
\hline Arkansas & 534.60 & 399.63 & 934.23 & 0.14 & 0 & 420.68 & 420.82 \\
\hline Ashley & 120.18 & 13.48 & 133.66 & 0.42 & 0 & 97.83 & 98.25 \\
\hline Benton & 0 & 0 & 0 & 0 & 0 & 0 & 0 \\
\hline Boone & 0 & 0 & 0 & 0 & 0 & 0 & 0 \\
\hline Bradley & 0 & 0 & 0 & 0 & 0 & 0 & 0 \\
\hline Calhoun & 0 & 0 & 0 & 0 & 0 & 0.06 & 0.06 \\
\hline Carroll & 0 & 0.16 & 0.16 & 0.09 & 0 & 0 & 0.09 \\
\hline Clay & 397.16 & 7.61 & 404.77 & 4.56 & 0 & 168.57 & 173.13 \\
\hline Cleburne & 0.13 & 0 & 0.13 & 0 & 0 & 0.05 & 0.05 \\
\hline Cleveland & 0 & 0 & 0 & 0 & 0 & 0 & 0 \\
\hline Columbia & 0 & 0 & 0 & 0 & 0 & 0 & 0 \\
\hline Conway & 1.02 & 4.87 & 5.89 & 1.62 & 0 & 3.93 & 5.55 \\
\hline Craighead & 356.54 & 50.04 & 406.58 & 3.41 & 0 & 258.11 & 261.52 \\
\hline Crawford & 0.66 & 0.63 & 1.29 & 0.64 & 0 & 1.55 & 2.19 \\
\hline Crittenden & 210.30 & 1.52 & 211.82 & 66.22 & 0 & 88.66 & 154.88 \\
\hline Fulton & 0 & 0 & 0 & 0 & 0 & 0 & 0 \\
\hline Garland & 0 & 0 & 0 & 0 & 0 & 0 & 0 \\
\hline Grant & 3.16 & 0 & 3.16 & 0 & 0 & 1.13 & 1.13 \\
\hline Greene & 339.09 & 10.54 & 349.63 & 4.97 & 0 & 145.87 & 150.84 \\
\hline Hempstead & 0 & 0 & 0 & 0 & 0 & 0 & 0 \\
\hline Hot Spring & 0 & 7.98 & 7.98 & 0 & 0 & 2.92 & 2.92 \\
\hline Howard & 0 & 0 & 0 & 0 & 0 & 0 & 0 \\
\hline Independence & 56.01 & 24.34 & 80.35 & 6.58 & 0 & 26.51 & 33.09 \\
\hline Izard & 0 & 0 & 0 & 0 & 0 & 0 & 0 \\
\hline Jackson & 415.30 & 22.37 & 437.67 & 20.50 & 0 & 194.45 & 214.95 \\
\hline Jefferson & 229.59 & 51.81 & 281.40 & 7.18 & 0 & 180.78 & 187.96 \\
\hline Johnson & 0 & 0 & 0 & 0 & 0 & 0.81 & 0.81 \\
\hline Lafayette & 19.09 & 0.76 & 19.85 & 2.97 & 0 & 11.64 & 14.61 \\
\hline Lawrence & 178.62 & 18.35 & 196.97 & 0.21 & 0 & 108.97 & 109.18 \\
\hline
\end{tabular}


Table 11. Irrigation water use in Arkansas, 2010.-Continued

[Mgal/d, million gallons per day; surface irrigation, flood or furrow irrigation; values may not sum to totals because of independent rounding]

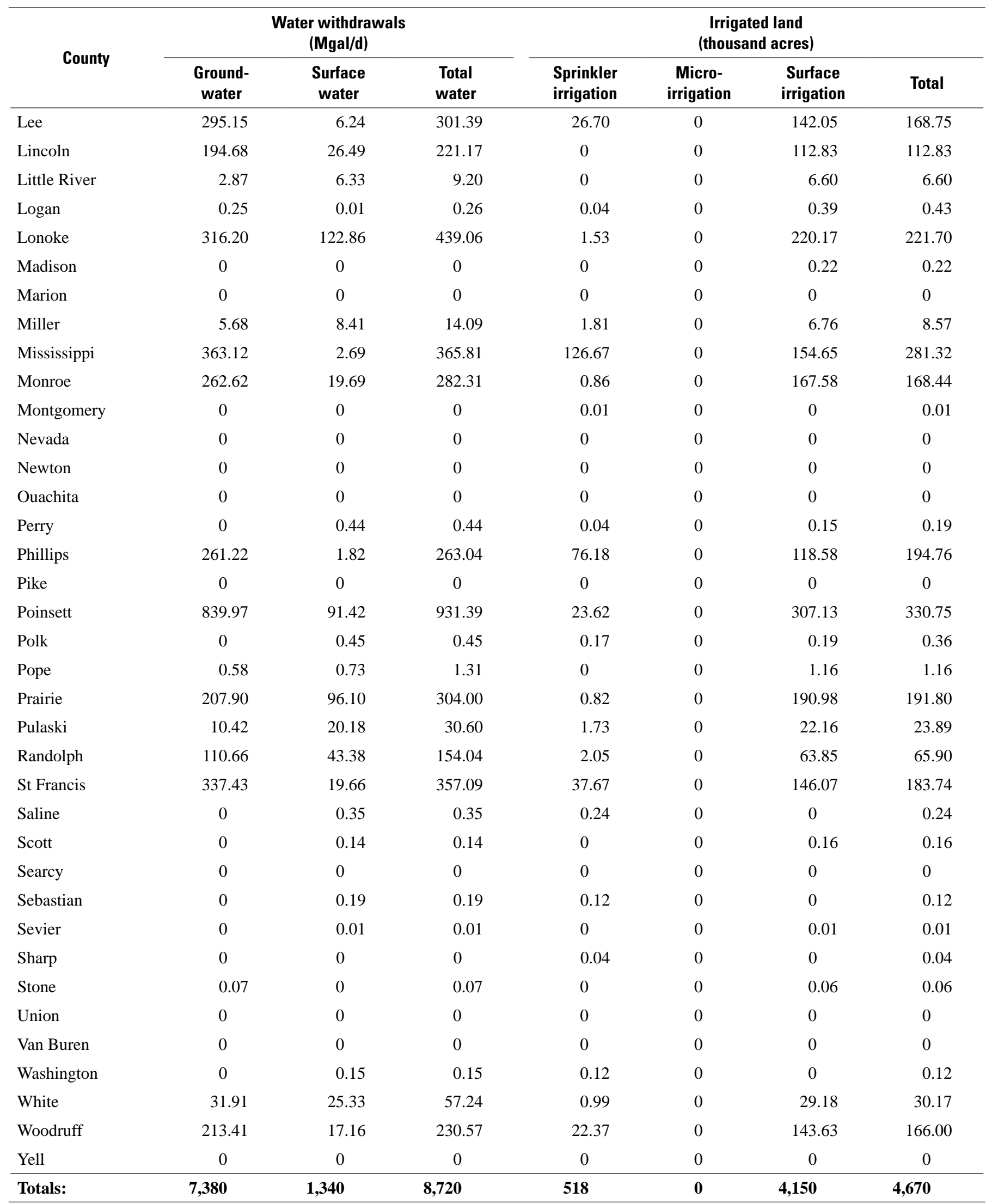


Table 12. Duck (hunting) clubs water use in Arkansas, 2010.

[Mgal/d, million gallons per day; values may not sum to totals because of independent rounding]

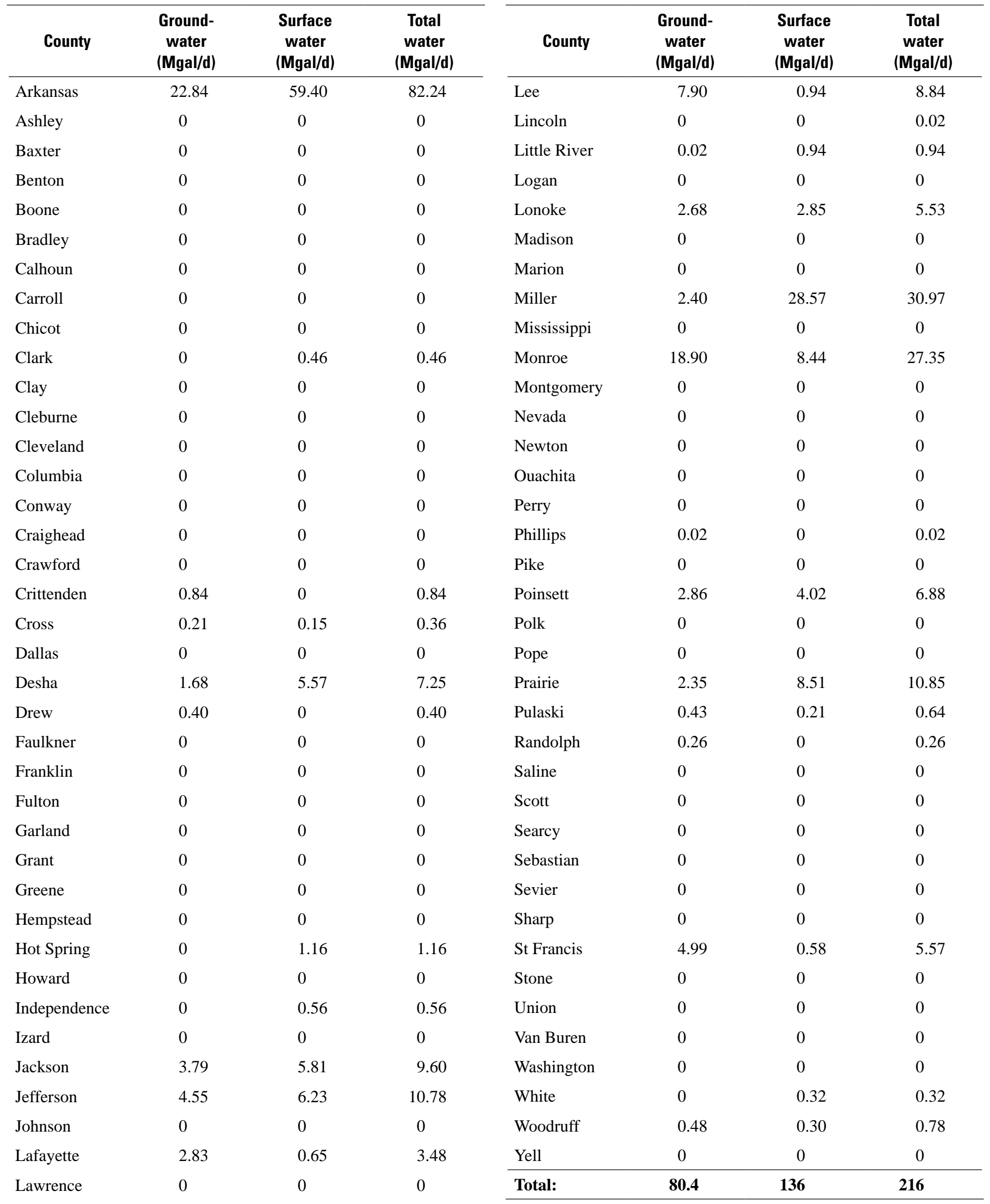




\section{Thermoelectric Power Generation}

Thermoelectric power generation includes power generated using fossil fuels, geothermal, or nuclear energy sources. Thermoelectric power water use includes water used in the process of power generation, including boilers (steam), cooling systems, and plant domestic uses. Cooling systems were separated as wet cooling towers or surface-water cooling systems that generally divert water for "once through" cooling and then return the water to a stream or lake. Total thermoelectric power water use in Arkansas for 2010 was about 1,540 Mgal/d, with less than 1 percent (4.26 Mgal/d) from groundwater sources and over 99 percent (about 1,540 Mgal/d) from surface water (table 13). Water used for thermoelectric power generation was about 14 percent of the total water used in Arkansas during 2010 and about 44 percent of the total surface water used. About 63 percent (972.93 Mgal/d) of the water used in this category was for cooling at a nuclear power plant in Pope County. Other counties with notable thermoelectric power generation water use (greater than 10 $\mathrm{Mgal} / \mathrm{d}$ ) were Benton, Hot Spring, Ouachita, Independence, Jefferson, and Woodruff (in order of decreasing use). Together, along with Pope County, these seven counties accounted for about 99 percent of all water use in this category.

\section{Changes in Water Use for Selected Categories, 1965-2010}

The three water-use categories with the largest withdrawals and their effects on total water use were examined. The irrigation water-use category accounted for 54 percent of the State's total water use in 1965 and 77 percent in 2010 (table 14). The thermoelectric power water-use category accounted for 20 percent of the State's total water use in 1965 and 14 percent in 2010. The public supply water-use category accounted for 5.9 percent of the State's total water use in 1965 and 3.8 percent in 2010.

Total water use in Arkansas has increased about 428 percent from 2,142 to 11,300 Mgal/d between 1965 and 2010 (fig. 6, table 14). Total groundwater use increased about 533 percent from 1,231 to 7,790 Mgal/d and total surface-water use increased about 289 percent from 911 to 3,540 Mgal/d.

Since about 2000, total water use in Arkansas has plateaued, peaking in 2005 at 11,428 Mgal/d (fig. 6, table 14). The plateauing of total water use is the result of decreasing surface-water use in the irrigation, thermoelectric power, and public-supply categories offsetting the continuing increases in groundwater use in the irrigation category. Before 1980, groundwater and surface water each provided about half of the total water used in Arkansas. Since 1980, groundwater has provided about two-thirds of the total water use in Arkansas.

An examination of total water use and irrigation water use changes over time demonstrates the increasing dominance of groundwater withdrawals for irrigation on Arkansas' total water use. In 1965, irrigation water use dominated the State's water use, accounting for 77 percent of groundwater use, 23 percent of surface-water use, and 54 percent of total water use in Arkansas (table 14). The dominance of irrigation on Arkansas' total water use continued to increase through 2005 when irrigation water use accounted for 95 percent of groundwater use, 38 percent of surface-water use, and 77 percent of total water use.

Total irrigation water use in Arkansas between 1965 and 2010 has increased about 652 percent from 1,160 to $8,720 \mathrm{Mgal} / \mathrm{d}$ (table 14). Irrigation groundwater use increased about 678 percent from 949 to $7,380 \mathrm{Mgal} / \mathrm{d}$, and irrigation surface-water use increased about 535 percent from 211 to 1,340 Mgal/d.

The continuing increase in total irrigation water use has occurred despite the fact that irrigation from surface-water sources peaked in 2000 (fig. 7). Irrigation from surface water has decreased since 2000, while irrigation from groundwater has continued to increase. Total irrigation water use since 2000 has continued to increase because irrigation from groundwater has increased at a greater rate than irrigation from surface water has decreased.

Withdrawals for thermoelectric power water use in Arkansas has continuously accounted for about half of the State's total surface-water use for the period 1965-2010. Thermoelectric power water use accounted for 46 percent of total surface-water use and 20 percent of total water use for the State in 1965 and 44 percent of total surface-water use and 14 percent of total water use for the State in 2010 (table 14). In 1975, thermoelectric power water use peaked for both percent of surface-water use (69 percent) and percent of total water use (34 percent). Groundwater withdrawals for thermoelectric power water use have always been relatively small, never accounting for more than one-half of 1 percent of total groundwater use in the State for the period 1965-2010.

Thermoelectric power water use in Arkansas between 1965 and 2010 increased 264 percent from 423 to $1,540 \mathrm{Mgal} / \mathrm{d}$ (table 14). Total water use for the thermoelectric power category peaked in about 2000 at 2,175 Mgal/d, a 414-percent increase in water use from 1965. From 2000 to 2010, thermoelectric power water use decreased 29 percent.

The percentage of Arkansas' population served by public water suppliers has continued to increase while the percentage of the State's total water use withdrawn by public water suppliers has remained relatively constant. In 1965, public water suppliers provided water to about 1.10 million people (58 percent of the State's population) withdrawing $127 \mathrm{Mgal} / \mathrm{d}$ (5.9 percent of the State's total water use). In 2010, public water suppliers provided water to about 2.77 million people (95 percent of the State's population) withdrawing $429 \mathrm{Mgal} / \mathrm{d}$ (3.8 percent of the State's total water use).

Public-supply water use in Arkansas between 1965 and 2010 increased about 238 percent from 127 to $429 \mathrm{Mgal} / \mathrm{d}$ (fig. 8, table 14). Between 1965 and 2010, the population served by public water supplies increased about 152 percent from approximately 1.1 to 2.77 million people, and the per capita use of public-supply water increased 35 percent from approximately 115 to $155 \mathrm{gal} / \mathrm{d}$. The increase in public-supply 
Table 13. Thermoelectric power water use in Arkansas, 2010.

[Mgal/d, million gallons per day; values may not sum to totals because of independent rounding]

\begin{tabular}{|c|c|c|c|c|c|c|c|}
\hline County & $\begin{array}{l}\text { Ground- } \\
\text { water } \\
\text { (Mgal/d) }\end{array}$ & $\begin{array}{c}\text { Surface } \\
\text { water } \\
\text { (Mgal/d) }\end{array}$ & $\begin{array}{c}\text { Total } \\
\text { water } \\
\text { (Mgal/d) }\end{array}$ & County & $\begin{array}{l}\text { Ground- } \\
\text { water } \\
\text { (Mgal/d) }\end{array}$ & $\begin{array}{c}\text { Surface } \\
\text { water } \\
\text { (Mgal/d) }\end{array}$ & $\begin{array}{c}\text { Total } \\
\text { water } \\
\text { (Mgal/d) }\end{array}$ \\
\hline Ashley & 0 & 0 & 0 & Lincoln & 0 & 0 & 0 \\
\hline Baxter & 0 & 0 & 0 & Little River & 0.35 & 0 & 0.35 \\
\hline Boone & 0 & 0 & 0 & Lonoke & 0 & 0 & 0 \\
\hline Bradley & 0 & 0 & 0 & Madison & 0 & 0 & 0 \\
\hline Calhoun & 0 & 0 & 0 & Marion & 0 & 0 & 0 \\
\hline Carroll & 0 & 0 & 0 & Miller & 0 & 0 & 0 \\
\hline Cleburne & 0 & 0 & 0 & Nevada & 0 & 0 & 0 \\
\hline Cleveland & 0 & 0 & 0 & Newton & 0 & 0 & 0 \\
\hline Columbia & 0 & 0 & 0 & Ouachita & 0 & 39.50 & 39.50 \\
\hline Conway & 0 & 0 & 0 & Perry & 0 & 0 & 0 \\
\hline Craighead & 0 & 0 & 0 & Phillips & 0.34 & 0 & 0.34 \\
\hline Crawford & 0 & 0 & 0 & Pike & 0 & 0 & 0 \\
\hline Crittenden & 0 & 0 & 0 & Poinsett & 0 & 0 & 0 \\
\hline Cross & 0 & 0 & 0 & Polk & 0 & 0 & 0 \\
\hline Fulton & 0 & 0 & 0 & Saline & 0 & 0 & 0 \\
\hline Garland & 0 & 0 & 0 & Scott & 0 & 0 & 0 \\
\hline Grant & 0 & 0 & 0 & Searcy & 0 & 0 & 0 \\
\hline Greene & 0 & 0 & 0 & Sebastian & 0 & 0 & 0 \\
\hline Hempstead & 0 & 0 & 0 & Sevier & 0 & 0 & 0 \\
\hline Hot Spring & 0 & 110.50 & 110.50 & Sharp & 0 & 0 & 0 \\
\hline Howard & 0 & 0 & 0 & Stone & 0 & 0 & 0 \\
\hline Independence & 1.20 & 28.80 & 30.00 & Union & 0 & 4.70 & 4.70 \\
\hline Izard & 0 & 0 & 0 & Van Buren & 0 & 0 & 0 \\
\hline Jackson & 0 & 0 & 0 & Washington & 0 & 0 & 0 \\
\hline Jefferson & 1.12 & 19.22 & 20.34 & White & 0 & 0 & 0 \\
\hline Johnson & 0 & 0 & 0 & Woodruff & 0.06 & 13.74 & 13.80 \\
\hline Lafayette & 0.35 & 0 & 0.35 & Yell & 0 & 0 & 0 \\
\hline Lawrence & 0 & 0 & 0 & Totals: & 4.26 & 1,540 & 1,540 \\
\hline
\end{tabular}


Table 14. Changes in water use for selected categories in Arkansas, 1965-2010.

[Mgal/d; million gallons per day; gal/d/p, gallon per day per person; $\leftarrow$ Smallest

Largest $\rightarrow$ ]

\begin{tabular}{|c|c|c|c|c|c|c|c|c|c|c|c|c|c|c|c|}
\hline \multirow[b]{2}{*}{ Year } & \multirow[b]{2}{*}{$\begin{array}{c}\text { State } \\
\text { population } \\
\text { (thousands) }\end{array}$} & \multicolumn{3}{|c|}{ Total } & \multicolumn{3}{|c|}{ Irrigation } & \multicolumn{3}{|c|}{ Thermoelectric power } & \multicolumn{5}{|c|}{ Public supply } \\
\hline & & $\begin{array}{l}\text { Ground- } \\
\text { water } \\
\text { (Mgal/d) }\end{array}$ & $\begin{array}{c}\text { Surface } \\
\text { water } \\
\text { (Mgal/d) }\end{array}$ & $\begin{array}{c}\text { Total } \\
\text { water } \\
\text { (Mgal/d) }\end{array}$ & $\begin{array}{l}\text { Ground- } \\
\text { water } \\
\text { (Mgal/d) }\end{array}$ & $\begin{array}{c}\text { Surface } \\
\text { water } \\
\text { (Mgal/d) }\end{array}$ & $\begin{array}{c}\text { Total } \\
\text { water } \\
\text { (Mgal/d) }\end{array}$ & $\begin{array}{c}\text { Ground- } \\
\text { water } \\
\text { (Mgal/d) }\end{array}$ & $\begin{array}{c}\text { Surface } \\
\text { water } \\
\text { (Mgal/d) }\end{array}$ & $\begin{array}{c}\text { Total } \\
\text { water } \\
\text { (Mgal/d) }\end{array}$ & $\begin{array}{c}\text { Population } \\
\text { served } \\
\text { (thousands) }\end{array}$ & $\begin{array}{l}\text { Ground- } \\
\text { water } \\
\text { (Mgal/d) }\end{array}$ & $\begin{array}{c}\text { Surface } \\
\text { water } \\
\text { (Mgal/d) }\end{array}$ & $\begin{array}{c}\text { Total } \\
\text { water } \\
\text { (Mgal/d) }\end{array}$ & $\begin{array}{c}\text { Per capita } \\
\text { use } \\
\text { (gal/d/p) }\end{array}$ \\
\hline 1965 & 1,894 & 1,231 & 911 & 2,142 & 949 & 211 & 1,160 & 5.9 & 417 & 423 & 1,100 & 54 & 73 & 127 & 115 \\
\hline 1970 & 1,923 & 1,530 & 1,531 & 3,061 & 1,064 & 229 & 1,266 & 4.1 & 952 & 957 & 1,240 & 71 & 95 & 166 & 134 \\
\hline 1975 & 2,160 & 2,596 & 2,468 & 5,064 & 2,094 & 346 & 2,440 & 2.5 & 1,715 & 1,717 & 1,485 & 89 & 117 & 206 & 139 \\
\hline 1980 & 2,327 & 4,051 & 2,845 & 6,897 & 3,484 & 598 & 3,992 & 3.1 & 1,779 & 1,782 & 1,627 & 110 & 153 & 263 & 162 \\
\hline 1985 & 2,359 & 3,808 & 2,101 & 5,909 & 3,333 & 541 & 3,874 & 1.1 & 1,094 & 1,095 & 1,681 & 101 & 156 & 257 & 153 \\
\hline 1990 & 2,353 & 4,708 & 3,128 & 7,836 & 4,296 & 949 & 3,874 & 2.4 & 1,638 & 1,641 & 1,780 & 119 & 190 & 309 & 173 \\
\hline 1995 & 2,484 & 5,456 & 3,311 & 8,767 & 4,926 & 1,010 & 5,936 & 5.2 & 1,766 & 1,771 & 1,996 & 135 & 246 & 381 & 191 \\
\hline 2000 & 2,673 & 6,925 & 3,948 & 10,872 & 6,506 & 1,407 & 7,913 & 2.9 & 2,172 & 2,175 & 2,323 & 132 & 289 & 421 & 181 \\
\hline 2005 & 2,779 & 7,507 & 3,922 & 11,428 & 7,378 & 1,341 & 8,265 & 0.93 & 1,996 & 1,997 & 2,579 & 138 & 266 & 404 & 157 \\
\hline 2010 & 2,916 & 7,790 & 3,540 & 11,300 & 7,380 & 1,340 & 8,720 & 4.3 & 1,540 & 1,540 & 2,770 & 134 & 295 & 429 & 155 \\
\hline
\end{tabular}

\begin{tabular}{|c|c|c|c|c|c|c|c|c|c|c|}
\hline \multirow[b]{2}{*}{ Year } & \multicolumn{3}{|c|}{ Irrigation } & \multicolumn{3}{|c|}{ Thermoelectric power } & \multicolumn{4}{|c|}{ Public supply } \\
\hline & $\begin{array}{c}\text { Total, } \\
\text { ground- } \\
\text { water } \\
\text { (percent) }\end{array}$ & $\begin{array}{c}\text { Total, } \\
\text { surface } \\
\text { water } \\
\text { (percent) }\end{array}$ & $\begin{array}{c}\text { State } \\
\text { total } \\
\text { water } \\
\text { (percent) }\end{array}$ & $\begin{array}{c}\text { Total, } \\
\text { ground- } \\
\text { water } \\
\text { (percent) }\end{array}$ & $\begin{array}{c}\text { Total, } \\
\text { surface } \\
\text { water } \\
\text { (percent) }\end{array}$ & $\begin{array}{c}\text { State } \\
\text { total } \\
\text { water } \\
\text { (percent) }\end{array}$ & $\begin{array}{c}\text { State } \\
\text { population } \\
\text { served } \\
\text { (percent) }\end{array}$ & $\begin{array}{c}\text { Total, } \\
\text { ground- } \\
\text { water } \\
\text { (percent) }\end{array}$ & $\begin{array}{c}\text { Total, } \\
\text { surface } \\
\text { water } \\
\text { (percent) }\end{array}$ & $\begin{array}{c}\text { State } \\
\text { total } \\
\text { water } \\
\text { (percent) }\end{array}$ \\
\hline 1965 & 77 & 23 & 54 & 0.48 & 46 & 20 & 58 & 4.4 & 8.0 & 5.9 \\
\hline 1970 & 70 & 15 & 41 & 0.27 & 62 & 31 & 64 & 4.6 & 6.2 & 5.4 \\
\hline 1975 & 81 & 14 & 48 & 0.09 & 69 & 34 & 69 & 3.4 & 4.8 & 4.1 \\
\hline 1980 & 86 & 21 & 58 & 0.08 & 63 & 26 & 70 & 2.7 & 5.4 & 3.8 \\
\hline 1985 & 88 & 26 & 66 & 0.03 & 52 & 19 & 71 & 2.6 & 7.4 & 4.4 \\
\hline 1990 & 91 & 30 & 49 & 0.05 & 52 & 21 & 76 & 2.5 & 6.1 & 3.9 \\
\hline 1995 & 90 & 31 & 68 & 0.09 & 53 & 20 & 80 & 2.5 & 7.4 & 4.3 \\
\hline 2000 & 94 & 36 & 73 & 0.04 & 55 & 20 & 87 & 1.9 & 7.3 & 3.9 \\
\hline 2005 & 98 & 34 & 72 & 0.01 & 51 & 17 & 93 & 1.8 & 6.8 & 3.5 \\
\hline 2010 & 95 & 38 & 77 & 0.05 & 44 & 14 & 95 & 1.7 & 8.3 & 3.8 \\
\hline
\end{tabular}




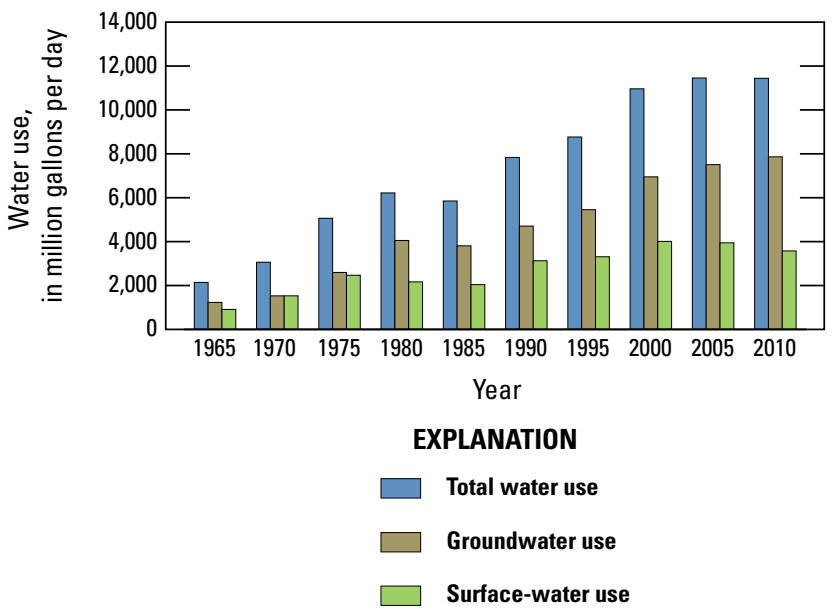

Figure 6. Total water, groundwater, and surface-water use in Arkansas, 1965-2010.

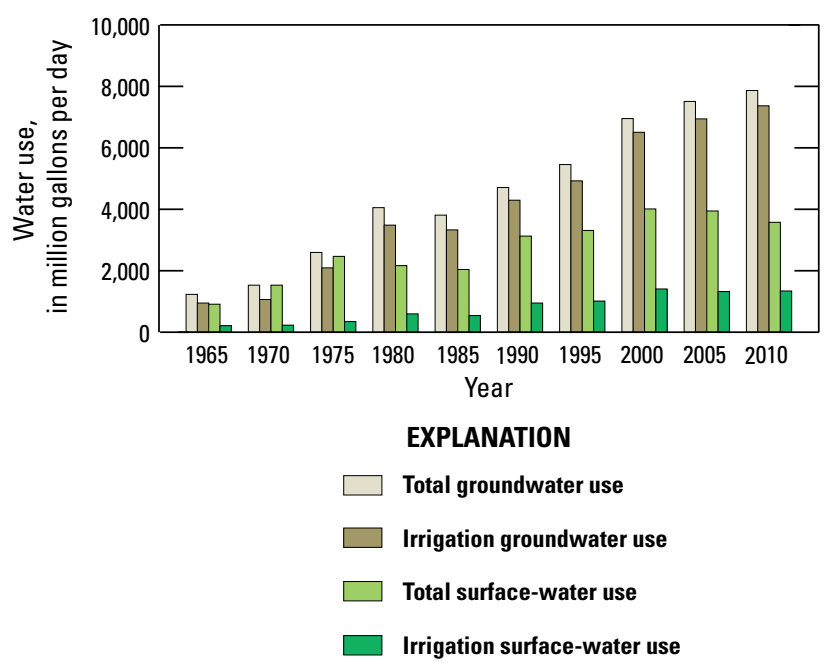

Figure 7. Total water and irrigation water use for groundwater and surface water in Arkansas, 1965-2010.

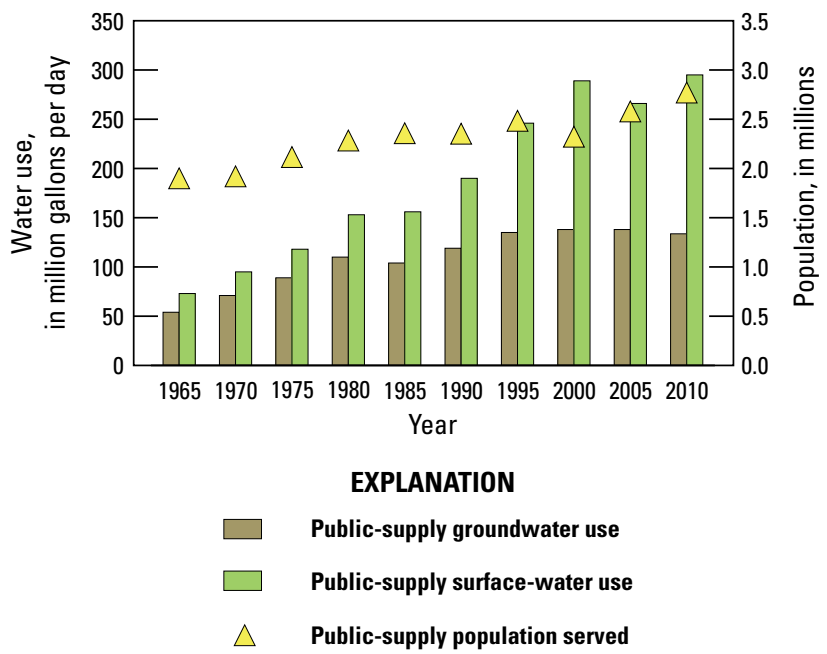

Figure 8. Groundwater and surface-water use and population served for public-supply systems in Arkansas, 1965-2010. water use for the 45-year period resulted from both an increase in population and an increase in average per capita water use.

Regardless of continuing increases in population, since about 2000, total public-supply water use in Arkansas has plateaued at about $425 \mathrm{Mgal} / \mathrm{d}$. (table 14). Groundwater public supply has remained between 132 and $138 \mathrm{Mgal} / \mathrm{d}$ since 2000, and surface-water public supply has remained between 266 and $295 \mathrm{Mgal} / \mathrm{d}$ since 2000 (fig. 8). Public supply per capita use was 155 gallons per day per person (gal/d/p) in 2010, a decrease of $2 \mathrm{gal} / \mathrm{d} / \mathrm{p}$ since 2005 . Historically, public supply per capita use has varied from a minimum of $115 \mathrm{gal} / \mathrm{d} / \mathrm{p}$ in 1965 to a maximum of $191 \mathrm{gal} / \mathrm{d} / \mathrm{p}$ in 1995.

\section{Sources of Groundwater Withdrawals}

Groundwater withdrawals comprised about 69 percent (7,790 Mgal/d) of the total amount of water used in Arkansas in 2010 (table 1). Four aquifers in Arkansas account for more than 99 percent of the total groundwater withdrawals. In order of decreasing withdrawals, the alluvial aquifer, mostly located within the Mississippi Alluvial Plain physiographic section; the Sparta-Memphis and Wilcox aquifers, located in the Coastal Plain physiographic division; and the Paleozoic aquifer, located in the Interior Highlands physiographic division (fig. 1).

In 2010, the alluvial aquifer supplied about 97 percent $(7,520 \mathrm{Mgal} / \mathrm{d})$ of all groundwater withdrawals. The five counties with the largest withdrawals from the alluvial aquifer were Poinsett (838.13 Mgal/d), Cross (518.39 Mgal/d),

Arkansas (482.99 Mgal/d), Jackson (429.16 Mgal/d), and Clay (396.25 Mgal/d), accounting for about 35 percent of the water withdrawn from the aquifer (table 15).

The Sparta-Memphis aquifer supplied about 2.5 percent (192 Mgal/d) of all groundwater withdrawals. The five counties with the largest withdrawals from the SpartaMemphis aquifer were Arkansas (56.71 Mgal/d), Jefferson (43.49 Mgal/d), Lonoke (16.45 Mgal/d), Craighead (13.36 Mgal/d), and Prairie (10.22 Mgal/d), accounting for about 73 percent of the total water withdrawn from the aquifer (table 15).

The Wilcox aquifer supplied about 0.5 percent (36.2 Mgal/d) of all groundwater withdrawals. The five counties with the largest withdrawals from the Wilcox aquifer were Mississippi (9.91 Mgal/d), Crittenden (7.08 Mgal/d), Greene (5.58 Mgal/d), Poinsett (3.32 Mgal/d), and Saline (2.74 Mgal/d), accounting for about 79 percent of the total water withdrawn from the aquifer (table 15).

The Paleozoic aquifer supplied about 0.3 percent (26.9 Mgal/d) of all groundwater withdrawals. The five counties with the largest withdrawals from the Paleozoic aquifer were Benton (5.69 Mgal/d), Fulton (1.89 Mgal/d), Boone (1.80 Mgal/d), Carroll (1.77 Mgal/d), and Searcy (1.54 Mgal/d), accounting for about 47 percent of the total water withdrawn from the aquifer (table 15). 
Table 15. Groundwater use by major aquifer in Arkansas, 2010.

[Mgal/d, million gallons per day; values may not sum to totals because of independent rounding]

\begin{tabular}{|c|c|c|c|c|c|c|c|c|c|c|c|}
\hline \multirow[b]{2}{*}{ County } & \multicolumn{11}{|c|}{ Aquifer in } \\
\hline & $\begin{array}{c}\text { Deposits of } \\
\text { Quaternary age }\end{array}$ & $\begin{array}{l}\text { Cockfield } \\
\text { Formation }\end{array}$ & $\begin{array}{l}\text { Sparta-Memphis } \\
\text { Sands }\end{array}$ & $\begin{array}{l}\text { Cane River } \\
\text { Formation }\end{array}$ & $\begin{array}{l}\text { Wilcox Group, } \\
\text { undifferentiated }\end{array}$ & $\begin{array}{l}\text { Clayton } \\
\text { Formation }\end{array}$ & $\begin{array}{l}\text { Nacatoch } \\
\text { Sand }\end{array}$ & $\begin{array}{c}\text { Tokio } \\
\text { Formation }\end{array}$ & $\begin{array}{l}\text { Trinity } \\
\text { Group }\end{array}$ & $\begin{array}{l}\text { Rock of Paleozoic } \\
\text { age, undifferentiated }\end{array}$ & $\begin{array}{l}\text { County } \\
\text { total }\end{array}$ \\
\hline Arkansas & 482.99 & 0.38 & 56.71 & 0 & 0 & 0 & 0 & 0 & 0 & 0 & 540.08 \\
\hline Ashley & 129.16 & 10.02 & 0 & 0 & 0 & 0 & 0 & 0 & 0 & 0 & 139.18 \\
\hline Baxter & 0 & 0 & 0 & 0 & 0 & 0 & 0 & 0 & 0 & 1.37 & 1.37 \\
\hline Benton & 0 & 0 & 0 & 0 & 0 & 0 & 0 & 0 & 0 & 5.69 & 5.69 \\
\hline Boone & 0 & 0 & 0 & 0 & 0 & 0 & 0 & 0 & 0 & 1.80 & 1.80 \\
\hline Bradley & 0 & 0.10 & 1.88 & 0 & 0 & 0 & 0 & 0 & 0 & 0 & 1.98 \\
\hline Calhoun & 0 & 0 & 0.63 & 0 & 0 & 0 & 0 & 0 & 0 & 0 & 0.63 \\
\hline Carroll & 0 & 0 & 0 & 0 & 0 & 0 & 0 & 0 & 0 & 1.77 & 1.77 \\
\hline Chicot & 201.19 & 1.95 & 0.47 & 0 & 0 & 0 & 0 & 0 & 0 & 0 & 203.61 \\
\hline Clark & 0 & 0 & 0 & 0 & 0 & 0 & 0.48 & 0.12 & 0 & 0.01 & 0.61 \\
\hline Clay & 396.25 & 0 & 0.12 & 0 & 0.80 & 0 & 1.21 & 0 & 0 & 1.43 & 399.81 \\
\hline Cleburne & 0.37 & 0 & 0 & 0 & 0 & 0 & 0 & 0 & 0 & 0 & 0.37 \\
\hline Cleveland & 0 & 0 & 1.16 & 0 & 0 & 0 & 0 & 0 & 0 & 0 & 1.16 \\
\hline Columbia & 0.07 & 0 & 9.36 & 0 & 0 & 0 & 0 & 0 & 0.04 & 0 & 9.47 \\
\hline Conway & 1.66 & 0 & 0 & 0 & 0 & 0 & 0 & 0 & 0 & 0 & 1.66 \\
\hline Craighead & 358.45 & 0 & 13.36 & 0 & 0.77 & 0 & 0 & 0 & 0 & 0 & 372.58 \\
\hline Crawford & 0.87 & 0 & 0 & 0 & 0 & 0 & 0 & 0 & 0 & 0 & 0.87 \\
\hline Crittenden & 211.13 & 0 & 0 & 0 & 7.08 & 0 & 0 & 0 & 0 & 0 & 218.21 \\
\hline Cross & 518.39 & 0 & 5.01 & 0 & 0.34 & 0 & 0 & 0 & 0 & 0 & 523.74 \\
\hline Dallas & 0 & 0 & 0.78 & 0 & 0 & 0 & 0 & 0 & 0 & 0 & 0.78 \\
\hline Desha & 365.24 & 2.01 & 3.96 & 0 & 0 & 0 & 0 & 0 & 0 & 0 & 371.21 \\
\hline Drew & 31.30 & 0 & 2.14 & 0 & 0 & 0 & 0 & 0 & 0 & 0 & 33.44 \\
\hline Faulkner & 4.53 & 0 & 0 & 0 & 0 & 0 & 0 & 0 & 0 & 0 & 4.53 \\
\hline Franklin & 0.47 & 0 & 0 & 0 & 0 & 0 & 0 & 0 & 0 & 0.01 & 0.48 \\
\hline Fulton & 0 & 0 & 0 & 0 & 0 & 0 & 0 & 0 & 0 & 1.89 & 1.89 \\
\hline Garland & 0 & 0 & 0 & 0 & 0 & 0 & 0 & 0 & 0 & 0.05 & 0.05 \\
\hline Grant & 3.39 & 0 & 1.73 & 0 & 0 & 0 & 0 & 0 & 0 & 0 & 5.12 \\
\hline Greene & 350.33 & 0 & 0 & 0 & 5.58 & 0 & 0.46 & 0 & 0 & 0 & 356.37 \\
\hline Hempstead & 0 & 0 & 0 & 0 & 0 & 0 & 1.29 & 2.12 & 0 & 0 & 3.41 \\
\hline Hot Spring & 0 & 0 & 0.23 & 0 & 0 & 0 & 0 & 0 & 0 & 0.22 & 0.45 \\
\hline Howard & 0 & 0 & 0 & 0 & 0 & 0 & 0 & 0.54 & 0 & 0 & 0.54 \\
\hline Independence & 58.67 & 0 & 0 & 0 & 0 & 0 & 0 & 0 & 0 & 0 & 58.67 \\
\hline Izard & 0 & 0 & 0 & 0 & 0 & 0 & 0 & 0 & 0 & 1.30 & 1.30 \\
\hline Jackson & 429.16 & 0 & 0.34 & 0 & 0 & 0 & 0 & 0 & 0 & 0 & 429.50 \\
\hline Jefferson & 234.93 & 1.12 & 43.49 & 0 & 0 & 0 & 0 & 0 & 0 & 0 & 279.54 \\
\hline Johnson & 0.35 & 0 & 0 & 0 & 0 & 0 & 0 & 0 & 0 & 0 & 0.35 \\
\hline Lafayette & 22.61 & 0.01 & 0.75 & 0.65 & 0.02 & 0 & 0 & 0 & 0 & 0 & 24.04 \\
\hline Lawrence & 179.35 & 0 & 0 & 0 & 0 & 0 & 0.01 & 0 & 0 & 0.55 & 179.91 \\
\hline
\end{tabular}


Table 15. Groundwater use by major aquifer in Arkansas, 2010.-Continued

[Mgal/d, million gallons per day; values may not sum to totals because of independent rounding]

\begin{tabular}{|c|c|c|c|c|c|c|c|c|c|c|c|}
\hline \multirow[b]{2}{*}{ County } & \multicolumn{11}{|c|}{ Aquifer in } \\
\hline & $\begin{array}{c}\text { Deposits of } \\
\text { Quaternary age }\end{array}$ & $\begin{array}{l}\text { Cockfield } \\
\text { Formation }\end{array}$ & $\begin{array}{c}\text { Sparta-Memphis } \\
\text { Sands }\end{array}$ & $\begin{array}{l}\text { Cane River } \\
\text { Formation }\end{array}$ & $\begin{array}{l}\text { Wilcox Group, } \\
\text { undifferentiated }\end{array}$ & $\begin{array}{l}\text { Clayton } \\
\text { Formation }\end{array}$ & $\begin{array}{l}\text { Nacatoch } \\
\text { Sand }\end{array}$ & $\begin{array}{c}\text { Tokio } \\
\text { Formation }\end{array}$ & $\begin{array}{l}\text { Trinity } \\
\text { Group }\end{array}$ & $\begin{array}{l}\text { Rock of Paleozoic } \\
\text { age, undifferentiated }\end{array}$ & $\begin{array}{l}\text { County } \\
\text { total }\end{array}$ \\
\hline Lee & 299.76 & 0 & 0.94 & 0 & 0.05 & 0 & 0 & 0 & 0 & 0 & 300.75 \\
\hline Lincoln & 194.18 & 0 & 3.23 & 0 & 0 & 0 & 0 & 0 & 0 & 0 & 197.41 \\
\hline Little River & 4.12 & 0 & 0 & 0 & 0 & 0 & 0 & 0 & 0 & 0 & 4.12 \\
\hline Logan & 0.71 & 0 & 0 & 0 & 0 & 0 & 0 & 0 & 0 & 0 & 0.71 \\
\hline Lonoke & 347.42 & 0 & 16.45 & 0 & 1.92 & 0 & 0 & 0 & 0 & 0 & 365.79 \\
\hline Madison & 0 & 0 & 0 & 0 & 0 & 0 & 0 & 0 & 0 & 0.93 & 0.93 \\
\hline Marion & 0 & 0 & 0 & 0 & 0 & 0 & 0 & 0 & 0 & 0.84 & 0.84 \\
\hline Miller & 6.67 & 0 & 0.01 & 0 & 0.02 & 0 & 0 & 0.15 & 0 & 0 & 6.85 \\
\hline Mississippi & 363.62 & 0 & 0 & 0 & 9.91 & 0 & 0 & 0 & 0 & 0 & 373.53 \\
\hline Monroe & 275.53 & 0.95 & 1.33 & 0 & 0 & 0 & 0 & 0 & 0 & 0 & 277.81 \\
\hline Montgomery & 0 & 0 & 0 & 0 & 0 & 0 & 0 & 0 & 0 & 0.20 & 0.20 \\
\hline Nevada & 0 & 0 & 0 & 0 & 0.22 & 0 & 0.21 & 0 & 0 & 0 & 0.43 \\
\hline Newton & 0 & 0 & 0 & 0 & 0 & 0 & 0 & 0 & 0 & 1.15 & 1.15 \\
\hline Ouachita & 0 & 0 & 1.16 & 0.07 & 0 & 0 & 0.01 & 0 & 0 & 0 & 1.24 \\
\hline Perry & 0.49 & 0 & 0 & 0 & 0 & 0 & 0 & 0 & 0 & 0 & 0.49 \\
\hline Phillips & 261.09 & 0 & 3.72 & 0 & 0 & 0 & 0 & 0 & 0 & 0 & 264.81 \\
\hline Pike & 0.64 & 0 & 0 & 0 & 0 & 0 & 0 & 0 & 0 & 0.01 & 0.65 \\
\hline Poinsett & 838.13 & 1.97 & 2.40 & 0 & 3.32 & 0 & 0 & 0 & 0 & 0 & 845.82 \\
\hline Polk & 0 & 0 & 0 & 0 & 0 & 0 & 0 & 0 & 0 & 1.15 & 1.15 \\
\hline Pope & 0.70 & 0 & 0 & 0 & 0 & 0 & 0 & 0 & 0 & 1.00 & 1.70 \\
\hline Prairie & 225.59 & 0 & 10.22 & 0 & 2.15 & 0 & 0 & 0 & 0 & 0 & 237.96 \\
\hline Pulaski & 14.09 & 0 & 0.86 & 0 & 0 & 0 & 0 & 0 & 0 & 0.03 & 14.98 \\
\hline Randolph & 111.38 & 0 & 0 & 0 & 0 & 0 & 0 & 0 & 0 & 0.05 & 111.43 \\
\hline St. Francis & 341.72 & 0.67 & 0.09 & 0 & 0.56 & 0 & 0 & 0 & 0 & 0 & 343.04 \\
\hline Saline & 1.32 & 0 & 0.49 & 0 & 2.74 & 0 & 0 & 0 & 0 & 0 & 4.55 \\
\hline Scott & 0 & 0 & 0 & 0 & 0 & 0 & 0 & 0 & 0 & 0.60 & 0.60 \\
\hline Searcy & 0 & 0 & 0 & 0 & 0 & 0 & 0 & 0 & 0 & 1.54 & 1.54 \\
\hline Sebastian & 0.24 & 0 & 0 & 0 & 0 & 0 & 0 & 0 & 0 & 0 & 0.24 \\
\hline Sevier & 0.81 & 0 & 0 & 0 & 0 & 0 & 0 & 0 & 0.14 & 0 & 0.95 \\
\hline Sharp & 0.01 & 0 & 0 & 0 & 0 & 0 & 0 & 0 & 0 & 1.38 & 1.39 \\
\hline Stone & 0.06 & 0 & 0 & 0 & 0 & 0 & 0 & 0 & 0 & 0.61 & 0.67 \\
\hline Union & 0.05 & 0 & 7.59 & 0 & 0 & 0 & 0 & 0 & 0 & 0 & 7.64 \\
\hline Van Buren & 0 & 0 & 0 & 0 & 0 & 0 & 0 & 0 & 0 & 0.25 & 0.25 \\
\hline Washington & 0 & 0 & 0 & 0 & 0 & 0 & 0 & 0 & 0 & 1.09 & 1.09 \\
\hline White & 31.73 & 0 & 0 & 0 & 0.68 & 0.15 & 0 & 0 & 0 & 0 & 32.56 \\
\hline Woodruff & 214.22 & 0 & 1.14 & 0 & 0 & 0 & 0 & 0 & 0 & 0 & 215.36 \\
\hline Yell & 0.45 & 0 & 0 & 0 & 0 & 0 & 0 & 0 & 0 & 0 & 0.45 \\
\hline Total: & 7,520 & 19.2 & 192 & 0.72 & 36.2 & 0.15 & 3.67 & 293 & 0.18 & 26.9 & 7,790 \\
\hline
\end{tabular}




\section{Summary}

The Arkansas Natural Resources Commission (ANRC) conducts an annual inventory of reported groundwater and surface-water withdrawals in Arkansas in cooperation with the U.S. Geological Survey (USGS). This report describes withdrawals from groundwater and surface-water resources in Arkansas for 2010. The report compiles withdrawals by county for 10 categories of water use-public supply, domestic (self-supplied), commercial (self-supplied), industrial (self-supplied), mining, livestock, aquaculture, irrigation, duck (hunting) clubs, and thermoelectric power generation. Water-use trends in Arkansas from 1965 to 2010 and sources of groundwater withdrawals also are described.

During 2010, total withdrawals from groundwater and surface-water sources in Arkansas were 11,300 million gallons per day (Mgal/d). Of the total withdrawn, about 69 percent (7,790 Mgal/d) was from groundwater. The largest total withdrawals generally occurred in eastern Arkansas and in counties along major rivers. The five counties with the largest total water use are Pope (987.15 Mgal/d), Arkansas (939.73 Mgal/d), Poinsett (937.26 Mgal/d), Cross (561.71 Mgal/d), and Lonoke (489.49 Mgal/d).

A summary of Arkansas' 2010 water use by category follows. Public-supply systems served about 2.77 million or about 94 percent of Arkansas' population. Public-supply total withdrawals were $429 \mathrm{Mgal} / \mathrm{d}$, with about 69 percent from surface-water sources. The statewide average of per capita residential use from public-supply systems was about 155 gallons per day (gal/d). All domestic (selfsupplied) withdrawals were assumed to be obtained from groundwater sources. The domestic (self-supplied) water use was $12.8 \mathrm{Mgal} / \mathrm{d}$. Total commercial (self-supplied) water use was $11.7 \mathrm{Mgal} / \mathrm{d}$, with about 92 percent $(10.8 \mathrm{Mgal} / \mathrm{d})$ from surface-water sources. Total industrial (self-supplied) water use was $276 \mathrm{Mgal} / \mathrm{d}$, with about 78 percent (214 $\mathrm{Mgal} / \mathrm{d}$ ) from surface-water sources. Total mining water use was $44.3 \mathrm{Mgal} / \mathrm{d}$, with over 99 percent (44.1 Mgal/d) from surface-water sources. Total livestock water use was 39.0 $\mathrm{Mgal} / \mathrm{d}$, with about 60 percent (23.4 Mgal/d) from surfacewater sources. Total aquaculture water use was $268 \mathrm{Mgal} / \mathrm{d}$, with about 68 percent (181 Mgal/d) from groundwater sources. Irrigation water use totaled $8,720 \mathrm{Mgal} / \mathrm{d}$, with about 85 percent (7,380 Mgal/d) from groundwater sources. Total duck (hunting) club water use was $216 \mathrm{Mgal} / \mathrm{d}$, with about 63 percent $(136 \mathrm{Mgal} / \mathrm{d})$ from surface-water sources. Total thermoelectric power water use was $1,540 \mathrm{Mgal} / \mathrm{d}$, with over 99 percent (1,540 Mgal/d) from surface-water sources.

The three water-use categories with the largest withdrawals and their effects on total water use were examined. Total water use in Arkansas has increased about 428 percent from 2,142 to 11,300 Mgal/d between 1965 and 2010. Total groundwater use increased about 533 percent from 1,231 to 7,790 Mgal/d, and total surface-water use increased about 289 percent from 911 to 3,540 Mgal/d. Since about 2000, total water use in Arkansas has plateaued and peaked in 2005 at 11,428 Mgal/d. The plateauing of total water use is the result of decreasing surface-water use in the irrigation, thermoelectric power, and public-supply categories offsetting the continuing increases in groundwater use in the irrigation category. An examination of total water use and irrigation water use changes over time demonstrates the increasing dominance of groundwater withdrawals for irrigation on Arkansas' total water use. Total irrigation water use in Arkansas between 1965 and 2010 has increased about 652 percent from 1,160 to 8,720 Mgal/d. The continuing increase in total irrigation water use has occurred despite the fact that irrigation from surface-water sources peaked in 2000. Withdrawals for thermoelectric power water use in Arkansas have continuously accounted for about half of the State's total surface-water use for the period 1965-2010. Thermoelectric power water use in Arkansas between 1965 and 2010 increased 264 percent from 423 to $1,540 \mathrm{Mgal} / \mathrm{d}$. The percentage of Arkansas' population served by public water suppliers has continued to increase while the percentage of the State's total water use withdrawn by public water suppliers has remained relatively constant. Public-supply water use in Arkansas between 1965 and 2010 increased about 238 percent from 127 to $429 \mathrm{Mgal} / \mathrm{d}$. Regardless of continuing increases in population, since 2000, total public-supply water use in Arkansas has plateaued at about $425 \mathrm{Mgal} / \mathrm{d}$.

Groundwater withdrawals comprised about 69 percent $(7,790 \mathrm{Mgal} / \mathrm{d})$ of the total amount of water used in Arkansas in 2010. Four aquifers in Arkansas account for more than 99 percent of the total groundwater withdrawals. The aquifers in deposits of Quaternary age supplied about 97 percent (7,520 Mgal/d) of all groundwater withdrawals. The SpartaMemphis aquifer supplied about 2.5 percent (192 Mgal/d) of all groundwater withdrawals, the Wilcox aquifer supplied about 0.5 percent (36.2 Mgal/d) of all groundwater withdrawals, and the Paleozoic aquifer supplied about 0.3 percent (26.9 Mgal/d) of all groundwater withdrawals.

\section{Selected References}

Arkansas Department of Health, 2011, 2010 Drinking water information for Arkansas: Arkansas Department of Health, accessed February 28, 2011, at http://www.healthyarkansas. com/eng/pwslist0.htm.

Fenneman, N.M., and Johnson, D.W., 1946, Physical divisions of the United States (Map): Washington, D.C., U.S. Geological Survey.

Halberg, H.N., 1972, Use of water in Arkansas, 1970: Arkansas Geological Commission Water Resources Summary 7, 15 p. (Also available at http://www.geology. ar.gov/water_summaries/wrs7.htm.)

Halberg, H.N., 1977, Use of water in Arkansas, 1975: Arkansas Geological Commission Water Resources Summary 9, 28 p. (Also available at http://www.geology. ar.gov/water_summaries/wrs9.htm.) 
Halberg, H.N., and Stephens, J.W., 1966, Use of water in Arkansas, 1965: Arkansas Geological Commission Water Resources Summary 5, 12 p. (Also available at http://www. geology.ar.gov/water_summaries/wrs5.htm.)

Hall, A.P., and Holland, T.W., 1984, Water use in Arkansas, 1981: U.S. Geological Survey Water-Resources Investigations Report 84-4070, 1 sheet. (Also available at http://pubs.er.usgs.gov/publication/wri844070.)

Holland, T.W., 1987, Use of water in Arkansas, 1985: Arkansas Geological Commission Water Resources Summary 16, 27 p. (Also available at http://www.geology. ar.gov/water_summaries/wrs16.htm.)

Holland, T.W., 1993, Use of water in Arkansas, 1990: U.S. Geological Survey Open-File Report 93-48, 1 sheet. (Also available at http://pubs.er.usgs.gov/publication/ofr9348.)

Holland, T.W., 1999, Water use in Arkansas, 1995: U.S. Geological Survey Open-File Report 99-188, 1 sheet. (Also available at http://pubs.er.usgs.gov/publication/ofr99188.)

Holland, T.W., 2004, Estimated water use in Arkansas, 2000: U.S. Geological Survey Scientific Investigations Report 2004-5230, 31 p. (Also available at http://pubs.er.usgs.gov/ publication/sir20045230.)

Holland, T.W., and Hall, A.P., 1986, Water use in Arkansas, 1982: U.S. Geological Survey Water-Resources Investigations Report 85-4282, 1 sheet. (Also available at http://pubs.er.usgs.gov/publication/wri854282.)

Holland, T.W., and Ludwig, A.H., 1981, Use of water in Arkansas, 1980: Arkansas Geological Commission Water Resources Summary 14, 30 p. (Also available at http://www.geology.ar.gov/water_summaries/wrs14.htm.)

Hutson, S.A., and others, 2004, Estimated use of water in the United States in 2000: U.S. Geological Survey Circular 1268, 46 p.

Kenny, J.F., and others, 2009, Estimated use of water in the United States in 2005: U.S. Geological Survey Circular 1344, $52 \mathrm{p}$.

MacKichan, K.A., 1951, Estimated water use in the United States-1950: U.S. Geological Survey Circular 115, 13 p.

MacKichan, K.A., 1957, estimated water use in the United States-1955: U.S. Geological Survey Circular 398, 18 p.

MacKichan, K.A., and Kammerer, J.C., 1961, Estimated water use in the United States, 1960: U.S. Geological Survey Circular 456, 26 p.
Maupin, M.A., Kenny, J.F., Hutson, S.S., Lovelace, J.K., Barber, N.L., and Linsey, K.S., 2014, Estimated use of water in the United States in 2010: U.S. Geological Survey Circular 1405, 56 p. (Also available at http://dx.doi. org/10.3133/cir1405.)

Murray, C.R., 1968, Estimated use of water in the United States, 1965: U.S. Geological Survey Circular 556, 53 p.

Murray, C.R., and Reeves, E.B., 1972, Estimated use of water in the United States, 1970: U.S. Geological Survey Circular 676, $37 \mathrm{p}$.

Murray, C.R., and Reeves, E.B., 1977, Estimated use of water in the United States, 1975: U.S. Geological Survey Circular 765, 37 p.

Petersen, J.C., Broom, M.E., and Bush, W.V., 1985, Geohydrologic units of the Gulf Coastal Plain in Arkansas: U.S. Geological Survey Water-Resources Investigations Report 85-4116, 20 p.

Solley, W.B., Chase, E.B., and Mann, W.B., 1983, Estimated use of water in the United States in 1980: U.S. Geological Survey Circular 1001, 56 p.

Solley, W.B., Merk, C.F., and Pierce, R.R., 1988, Estimated use of water in the United States in 1985: U.S. Geological Survey Circular 1004, 82 p.

Solley, W.B., Pierce, R.R., and Perlman, H.A., 1993, Estimated use of water in the United States in 1990: U.S. Geological Survey Circular 1081, 76 p.

Solley, W.B., Pierce, R.R., and Perlman, H.A., 1998, Estimated use of water in the United States in 1995: U.S. Geological Survey Circular 1200, 71 p.

Stephens, J.W., and Halberg, H.N., 1961, Use of water in Arkansas, 1960: Arkansas Geological Commission Water Resources Special Report Series 294, 56 p.

U.S. Department of Agriculture, 2010, Data and statistics: National Agricultural Statistics Service, accessed November 28, 2012, at http://www.nass.usda.gov/Data_and_Statistics/ index.asp.

U.S. Department of Commerce, U.S. Census Bureau, 2010: Census 2010 summary file (SF1) 100-percent data, accessed December 1, 2011, at http://factfinder.census.gov/servlet/ DTGeoSearchBYListServlet?ds_name=Dec_2010_SF!U\&lang=en\&ts=90149465759.

Webster, 2015, Webster's online dictionary: Accessed April 24, 2015, at http://www.webster-dictionary.org/definition/ hunt\%20club. 


\section{Glossary}

Water-use terminology continues to evolve as the field grows and expands. The following is a list of definitions for terms, phrases, and various data-collection components commonly used in the process of water-use data collection and compilation.

Acre-foot of water (acre-ft) The volume of water required to cover 1 acre of land (43,560 square feet) to a depth of 1 foot.

Acres irrigated The total number of acres of the crop that was irrigated during the year.

Aquaculture Farming of organisms that live in water, such as fish, shellfish, and algae. Reported water-use for aquaculture does not include usage by government fish hatcheries.

Aquifer A geologic formation, group of formations, or part of a formation that contains sufficient saturated permeable material to yield significant quantities of water to wells and springs.

Commercial water use Water for motels, hotels, restaurants, office buildings, schools, and other commercial facilities and institutions, both civilian and military. The water may be obtained from a public supply facility or may be selfsupplied. See also public supply and self-supplied water.

Cooling water Water used for cooling purposes, such as cooling of condensers and nuclear reactors.

Domestic population served The total number of people served by the public supplier during the calendar year.

Domestic water use Water used for household purposes, such as drinking, food preparation, bathing, washing clothes and dishes, flushing toilets, and watering lawns and gardens, also called residential water use. The water may be obtained from a public supply facility or may be self-supplied. See also public supply and self-supplied water.

Duck (hunting) club are associations of huntsmen who hunt for sport.

Freshwater Water that contains less than $1,000 \mathrm{mg} / \mathrm{L}$ (milligrams per liter) (but generally between less than 500 and $1,000 \mathrm{mg} / \mathrm{L}$ in Arkansas) of dissolved solids and is desirable for drinking and many industrial uses.

Groundwater Generally all subsurface water and springs as distinct from surface water; specifically, that part of the subsurface water in the saturated zone (a zone in which all voids are filled with water) where the water is under pressure greater than atmospheric.

Industrial water use Water used for industrial purposes, such as fabrication, processing, washing, and cooling, and includes such industries as steel, chemical and allied products, paper and allied products, mining, and petroleum refining. The water may be obtained from a public supply facility or may be self-supplied. See also public supply and self-supplied water.

Instream use Water use taking place within the stream channel for such purposes as hydroelectric power generation, navigation, water-quality improvement, fish propagation, and recreation. Sometimes called nonwithdrawal use or in-channel use.

Irrigation Refers to the process of supplementing rainfall with water that is needed to produce a crop.

Irrigation water use Artificial application of water on lands to assist in the growing of crops and pastures or to maintain vegetative growth in recreational lands, such as parks and golf courses.

Livestock water use Water for stock watering, feedlots, dairy operations, fish farming, and other farm needs. Livestock as used here includes cattle, sheep, goats, hogs, and poultry. Also included are such animal specialties as horses, rabbits, bees, pets, and fur-bearing animals in captivity.

Mining water use Water use for the extraction of minerals occurring naturally, including solids, such as coal, clay, and ores; liquids, such as crude petroleum; and gases, such as natural gas. Also includes uses associated with sand, gravel, and quarrying for rock aggregates, well operations (dewatering), milling (crushing, screening, washing, floatation, and other), and other preparations customarily done at the mine site or as part of a mining activity.

Per capita use The average amount of water used per person during a standard time period, generally per day.

Public supply Water withdrawn by public and private water suppliers and delivered to groups of users. Public suppliers provide water for a variety of uses, such as domestic, commercial, thermoelectric power generation, industrial, and public water use. See also commercial water use, domestic water use, industrial water use, and public water use.

Public water use Water supplied from a public water supply and used for such purposes as firefighting, street washing, and municipal parks and swimming pools. See also public supply.

Self-supplied water Water withdrawn from a groundwater or surface-water source by a user rather than being obtained from a public supply facility.

Thermoelectric power generation Electrical power generated using fossil fuel (coal, oil, or natural gas), geothermal, or nuclear energy.

Thermoelectric power water use Water used in the process of the generation of thermoelectric power. The water may be obtained from a public supply facility or may be selfsupplied. See also public supply and self-supplied water.

Water consumed or consumptive use Refers to that part of water withdrawn that is no longer available because it 
has evaporated, been incorporated into products and crops, consumed by man or livestock, or otherwise removed from the water environment.

Water use Describes how and where the water was used and in what amounts.
Withdrawal The amount of water withdrawn from a source (ground or surface). This is equivalent to "intake," "water diversion,” or "pumpage,” terms commonly used by industry and for irrigation and public supply, respectively. 


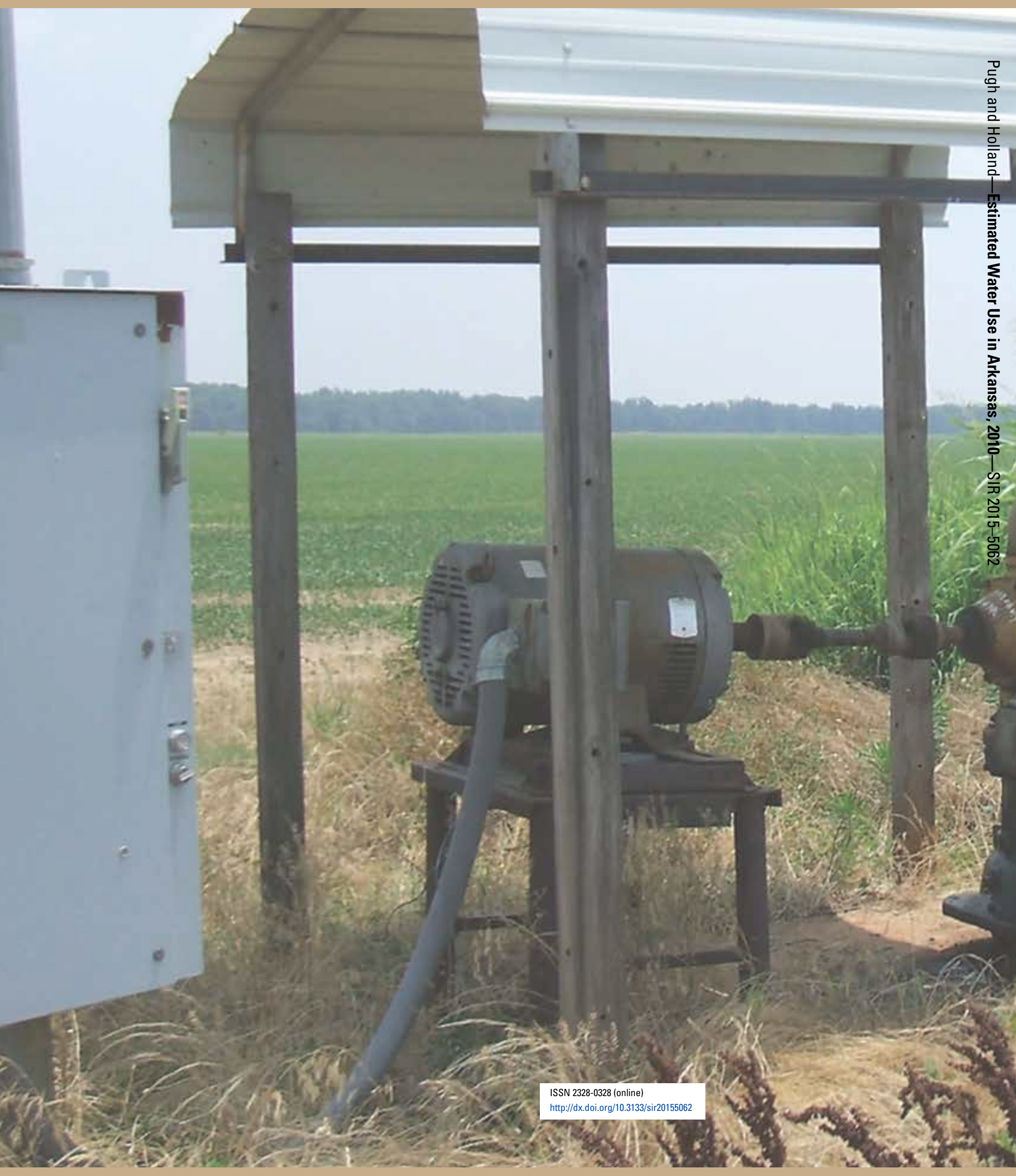

